\title{
The Doom of Employees' Training in Public Service - A Case Study of Ministry of Education in Kenya
}

\author{
Jacob M. Mbijjiwe ${ }^{1}$, Prof. P. Venkataiah ${ }^{2}$ \\ ${ }^{1}$ (PhD Research Scholar in Management, Osmania University, Hyderabad-India) \\ ${ }^{2}$ (Professor, University College of Commerce and Business Management, Osmania University-Hyderabad)
}

\begin{abstract}
Employee training, whether in private or public sector is a mandatory exercise if the employees have to deliver what is expected of them. Many times organizations have failed to achieve their objectives simply because the employees lack the motivation, skills or the new technical knowledge that is required for one to be effective in the current job environments. To assess the success and failures of employee training in the public service in Kenya, the Ministry of Education was sampled out for study. Questionnaires were used to gather data from 364 employees out of the 5000 employees of the Ministry. Averages, ratios, standard deviation and analysis of variances (ANOVA) were some of the tool used to analyze the data. Implementation of various HRD practices across job groups, experience levels and departments was studied and revealed glaring gaps between what was proposed in training manuals and what was actually happening. It was clear that departments, job positions and experience played an undue advantage or disadvantage to some employees' opportunities for training. The study also revealed that some HRD practices were never taken seriously while others were unnecessarily over emphasized. The study found out that TNA recommendations are rarely implemented and programs evaluation is done for accounting purposes and prove of activity not necessarily to improve training. The study suggests;

- That there should be constant evaluation of training programs

- There should be more officers with HRD background

- There should be centralized training

- Performance appraisal should be taken more seriously

- All HRD practices should be supported by a policy and documentary frame work

Keywords: - Evaluation, Induction, Orientation, Policies, TNA
\end{abstract}

\section{1: Background of the Study}

\section{Introduction}

To survive today, every organization, public or private has to look at ways to tap the knowledge base of every employee. Organizations have to innovate and put in place processes and policies that encourage employees to constantly seek new knowledge and ideas. These could range from reward schemes, internal reorganizations, to not only initiating training programs but also evaluating them for efficiency and effectiveness. After colonial rule many African governments inherited Public Service bodies that were used by the colonial governments mainly as instruments of law enforcement, suppression and tax collection. After independence the governments were faced with the problem of coming up with policies and structures that will address social economic problems of the then new order.

Some governments took over the public service staff as they were while others adopted an Africanization policy aimed at placing Africans at various key positions in the government public service bodies. Kenya chose the latter which called for additional recruitment and accelerated training to replace the foreigners and fill new positions.

Serious aggressiveness and enthusiasm was eminent in institutions and capacity development programs. But even with that early challenge training in the Public Service has for a long time been down played or left as a reserve of very few members of staff. Those who have been eager to seek training opportunities have mostly been those in the research related fields.

It is quiet disheartening to realize that close to $47 \%$ of the civil servants in Kenya cannot do simple tasks using a computer; it could be higher in other parts of Africa. A good deal of them have resisted all the efforts to have them upgrade their computer skills, but the bigger problem could be from the misplaced opportunities evident from those charged with the responsibility of conducting the training function in the various Ministries. What cannot be denied is that, Civil Service today is in a period of change and flexibility such as it has never experienced. If officers want to be competitive they have to bolster their positions in the in public service by mastering the new techniques offered by the competitive world.

The public service in Kenya has for a longtime assumed the importance of personnel training to an extent that employees might join the service and eventually retire without having gone for any skills upgrading 
course. Lately the issue of training is getting into the public service after realization that when you do not pay to train you will pay inform of losses, damages, strikes, poor services, employee turnovers and many other ways. There is recognition that training is an important avenue for development while at the same time it is a key tool for enhancing job-related performance and organizational effectiveness. Not to be lost is its value in engendering behavioral changes and in developing life skills leading to personal and career growth. But even with this realization the biggest problem is how the training function in the public service is conducted.

Conducting training in the public service in a manner that fosters employee development requires identification and management of those aspects of the training program that influence the learning process. This could be lacking in the public service as evidenced in Kenya and specifically Ministry of Education in that training programs have rarely been vetted for their ability to impart the knowledge and skills required. Methods of training should be such that they are commensurate with the employees' age, cadre, academic level, experience and understanding.

As they facilitate growth and development in employees, training programs should struggle to improve the employees to become more effective leaders, workers, decision makers, planners, presenters and facilitators. Studies have shown that the most successful and productive employees are those who have received extensive training. Some public sectors treat training as optional because they consider it an expense rather than an investment. While it can be costly it is also a long term investment in the growth and development of any organization. Simply put, training should be viewed like an input in a production process.

The other element characteristic of the civil service is the low staffing establishment in the training departments that are supposed to organize the training function in the ministries.DPM (2005) openly confesses that in Kenya, the training departments have problems that include inadequate supply of qualified professional, technical and managerial personnel to match the institutional growth that is being implemented.

For the civil service to have a productive workforce there has to be policies and guidelines to chart the way forward on the development procedures to follow. Mamoria et al (2007) categorically says that the existence of a policy on management and development makes clear to everyone what the intentions of the Board of Directors are and it sets out the context with the detailed plans and techniques it will fit. The preparation of a policy statement compels the top management to define their reason for investing money and spending time in systematic management development. Policies bring harmony in the way human resource development issues are handled in the various sectors. This should be the rule of thumb, not only to the private sector but also the public sector. This may not be happening in the public service employees in the better part of Africa.

\section{2: Statement of the Problem}

The fast rate of technological development demanded an even faster rate of improvement of the employee skills to man the tools and machines at work. Leazes (1995) notes that a well designed and implemented training program contributes to the educational growth and professional development of human service staff by improving the knowledge, skills and attitudes that enable employees to meet the service goals of an agency. The need for training and employee development cannot be downplayed, notes Vance (2006) as quoted by Rao, D.V. (2009, pg 46) in his study on employee engagement, employee development is a big driver to employee engagement since employees feel that specific efforts are being made by their company or manager to develop the employees skills. The entire African civil and public service has been slow on this looking a bit unsure of whether engagement is a priority especially in the public service. The assumption has always been that all and sundry will automatically work with dedication to the government.

May be the worst mistake many public service department make is failure to hold an orientation and induction exercise for new recruits. The Handbook for Civil Service Staff Induction (2006) in Kenya defines induction as a process that enables a new employee to adapt and acquaint themselves with the position and organizational environment. New officers should commence with orientation immediately upon reporting so that they get to know the objectives, policies, culture, standards, norms, traditions, resources and their responsibilities in the organization. A very recurrent phenomenon is that some officers have never had these training years down the line and even after hopping from one department to another.

Dolezalek (2007) found out that even in organizations with centralized training structure, some departments go off on their own to arrange training with vendors without even informing the training departments which ends ups with a training result that is uncomfortable, ineffective and inefficient. The last couple of years have seen a lot of such misuse in the Ministry of Education with very many haphazard training programs some of which could not be justified, accounted for or traced.

A vital input to training which is an obvious absentee in most countries in Africa is the Training Needs Assessment (TNA). Goldstein (2007) says that, it is very unfortunate some programs have not gone through appropriate needs assessment, and many organizations do not collect the information to determine the usefulness of their own instructional programs. Their techniques remain unevaluated, except for the high esteem with which they may be regarded by their developers. It should be noted that program developers are simply in 
business and will always try and market their products in the best way possible. This puts the organization to undue losses and a negative attitude towards training.

The other aspect of inefficiency by the training departments in Africa is the implementation of policies issued by the various directorates in charge of Personnel Management. Training and capacity building in the public service has been guided by circulars, general letters, policies, and other directives issued to the service from time to time. Training needs analysis has not been adequately conducted thereby making training more supply driven. This means the key areas of needs are rarely targeted by training hence lack of effectiveness.

The concept of training evaluation has received widespread recognition in theoretical dimensions but the actual process of evaluation has lagged behind. Sims Ronald (1993) declares that lack of training program evaluation is even more evident in the public sector and is possibly the least developed aspect of the training process in the public agencies. This is echoed by DPM (2005) in a statement that training evaluation and its cost effectiveness has also not been comprehensively undertaken. This means it is difficult to know whether or not the training targets have been achieved and if they have been achieved in an economically efficient way. The effect of these deficiencies has been poor training impact and service performance. Without strict adherence to the set policy guidelines and directions training will more often than not result to losses.

Sims Rowland(1993)concludes that recent research has shown that more than one third of the members of the American society of Training and development responding to a survey reported that evaluation was the most difficult aspect of their jobs but two fifth of the responding organization reported significant changes when training effectiveness was evaluated. The situation could be worse in Kenya hence the need for detailed evaluation exercise for the training programs.

To improve on the training it is the high time Ministries ensured that the training process is constantly evaluated and corrections made. To borrow from Shive Khera (2002, p 31), to improve on tree cutting, "after every tree I cut, I take a break for two minutes and sharpen my axe. When was the last time you sharpened your axe?" Past glory and strong academic grades from our education institutions and systems don't count for much. We have to continuously sharpen the axe and in organizations, training is the honing stone, Training departments need to critically look at this question in a way to get insight on when they lastly tried to evaluate their work and what collections they have made.

Performance appraisal is another practice poorly done in Africa. A study by Ramuvhundu M.N. (2012) in his research on Evaluating the impact of local government performance management systems on service delivery revealed that Performance measurements employed in Roads and Stormwater were unrealistic and in most cases were never agreed between the line manager and the concerned employee. Various weaknesses exist due to the fact that performance management is a relatively new domain in public service in Africa.

Career development and mentoring are also necessary practices that have not been very prevalent in the public service in Kenya. Progression and promotions have in most cases been determined by political, racial, ethnic and other un-friendly considerations than one's abilities. This is an area that needs to be improved remarkably. Career development and mentoring are also seen as important tools in helping to develop female leaders and employees from marginalized societies in Africa. It is for this reason that career development is a target topic for this research paper.

In the current work environments there are a myriad of factors that put employees to stressful situations. These could be retirements, stagnation, lay-offs, high targets to be achieved, economic hardships, family issues and many more. These therefore calls for the employers both public and private to put mechanisms in place to identify and counsel their employees when such situations arise. It is therefore very prudent to check if such activities have been put in place and to what level of success by the public service sector in the Kenyan setting.

\section{3: Justification of the Study}

It is inevitable that employers will have to strive to continuously hone the skills, knowledge, abilities and attitudes of their employees. This is a demand due to the rapidly changing technologies and the ever increasing need of employees to have interpersonal and problem solving skills. The same case applies to the public service organizations that hitherto had assumed the importance of human resource development to their performance. To quote the Minister of State for Public Service, as appeared in The Public Service Update (2010), "the Ministry will not only secure and retain employees with appropriate skills and knowledge but it will also ensure that the employees are morally and ethically up right. This will ensure that the Public Service is composed of people citizens can rely on to manage its affairs effectively and efficiently. But all may not be well as far as implementing the training programs in the Ministry of Education if the hullabaloo in the Ministry is anything to go by.

The purpose of this study is to bring to the fore the weaknesses that are prevalent in the HRD directorates in the Ministry. 
The study shows that in the Ministry of Education there is little or no evaluation done on the training programs and also evaluation of job performance after training.

There is every reason to do study on Ministry of Education due to its strategic position and advantage to the entire economy of the Republic of Kenya. This is one of the few Ministries that have a huge ripple effect to the whole country since it has representation in every sub - Location of the nation. The Ministry of Education dictates the supply of Human Resources to all the sectors of the economy. This is because of the effect and influence it has on school education, colleges, Technical Institutes and the Universities.

The Ministry of Education has the distinction of being the Ministry that consumes the highest allocation of the budget of the Republic. Apart from the national budget it also attracts a huge support from international donor funding and NGOs. Much of this funding targets Human Resource development in the country at large. This therefore makes the Ministry a very rich area for study.

\section{4: Objectives of the Study \\ 1.4.1General Objective}

The study identified HRD practices and measured their level of implementation so as to establish how well training programs are taken seriously in the Ministry of Education in Kenya.

\subsubsection{Specific Objectives}

These were;

1) To assess if the practices are uniformly implemented throughout the departments of the Ministry.

2) To assess if the practices are uniformly implemented across all the employees in terms of their experience.

3) To assess if the practices are uniformly implemented across all the job levels of the employees.

4) To suggest the significant HRD practices for the enhancement of employees' performance in the Ministry of Education and the entire Public Service in Kenya.

\section{5: Research Hypotheses}

\section{Hypothesis 1}

There is no significant difference in the way the HRD practices are implemented across the departments of the Ministry.

\section{Hypothesis 2}

There is no significant difference in the way HRD practices are implemented across the experience levels of employees in the Ministry.

\section{Hypothesis 3}

There is no significant difference in the way HRD practices are implemented across the Job Levels of employees in the Ministry.

\section{6: Limitations of the Study}

According to Mugenda and Mugenda (1999) limitations are the anticipated difficulties that might hinder the effective data collection process of any study which might also reduce the scope, the sample and the extent to which the generalization of the findings could be made.

This study is likely to face the following limitations:-

i. There might be no records kept in the Ministry on some critical issues like records of trained people for the past years;

ii. In some cases the staff members may not give truthful answers to the questionnaire so as not to expose their departmental weaknesses;

\section{7: Assumptions}

i. The Ministry has an independent HRD unit or Performance appraisal officer who appraises the employees.

ii. The respondents would be co-operative and knowledgeable enough to fill in the questionnaire.

\section{1: Introduction to the Ministry of Education in Kenya}

\section{Review Of Literature}

The ministry of Education in Kenya is by and large viewed as one of the most important ministries in Kenya, alongside Ministry of Health and Ministry of Agriculture. The three share the distinctions of being the most highly funded ministries and being the most rural based ministries. The Ministry of Education is captured under the social pillar in the national development blue print - Vision 2030. The Ministry is specially shared with the responsibility of ensuring that there is access, equity, efficiency, relevance and quality in education and training in the country. It is envisaged that improved quality in education and training will produce Kenyans 
with globally competitive skills that will provide the country with manpower to propel it to a middle level economy by the year 2030 .

It is for this reason that the research is entirely on this very pivotal Ministry as a yard stick to gauge other Ministries and also make suggestions on how best HRD practices can be improved in the other Ministries and Public service at large. The impact it has in the development endeavors of the country is enormous.

\subsection{Introduction}

This chapter deals with the survey of all literature related to the problem being investigated. Academic journals, government reports, research thesis, books, published and unpublished articles as well as material from the internet will be reviewed. Various studies have been done on training but few have given emphases on the impact various Human Resource development practices have on the entire organization and how training programs are planned and eventually mounted in the government ministries. Once budgeting and financial allocation has been done rarely is any following up done to verify whether the targeted objectives were achieved? To borrow from educationists Mbiti (1973) in any organization including a school, it is important to have managers who are able to implement policy guidelines and effectively perform supervisory duties. MSPS (2006), confess that training in the Civil Service is faced with following challenges;

- Training funds and opportunities are often skewed in favor of individuals, departments, cadres and even Ministries.

- That some officers enjoy favoritism in selection where due selection process is manipulated.

- That some officers go for non-work related training purely for personal benefit and at the expense of others.

As far as budgeting of ministries is concerned, there is always very low allocation to the training departments. It should be noted that organizations invest considerable amount of money in training but when the economy declines, the training budget is usually one of the first to be reduced. This clearly indicates that world over training has been assumed especially when it comes to budgeting. This is further echoed by Derek et al (2005) when he points out that it is only in Sweden and France do more than a quarter of the organizations surveyed spend more than 4 per cent of the pay bill on training. With the exception of France, the majority of organizations in each of the other countries spent less than 2 percent of their pay bill on training.

Public sector organizations need to borrow from the corporate world in terms of how much they spend on human resource development, Aswathappa (2008) observes that FedEx spends US\$155 million on training every year. The company allocates nearly 1,523 man-hours every year on training and development and each employee spends four to six weeks in a year in compulsory training besides 15 days of voluntary courses and a additional sum of US $\$ 2,500$ as tuition refund. The same trend needs to be followed by public service bodies if they have to offer services to the citizenly as required of them.

The justification for the spending on training is also rarely asked for Dolezalek (2007) summarizes that like an art, financing training means making decisions, thinking proactively, and taking some chances. Like a science, it often means sitting down with a spreadsheet and basing your decision on numbers and concrete goals. Once it is done, anyone involved with the budget has to hope he or she has made good decisions and money will be spent on learning experiences to company needs and nothing has been overlooked. This is a clear testimony to the fact that training is left as a trial and error issue. It is clearly shows that there is no guide as to what is to be done and what evaluative measure need to be put in place to avoid the "just hoping all is well". Dessler (2008) categorically states that in today's performance based environment, employers naturally expect their human resource management teams to provide measurable evidence of their efficiency and effectiveness and that of their proposed programs.

When the training procedures and policies are never followed it clearly shows that in the final analysis there is organizational loss that may never be clearly quantified. It is clear that many public ministries do not have a T.N.A to guide their training projections and priorities. This is not an isolated case for Kenya as Sreekumar (2009) discovered of the training departments in India. He quips, if Human Resource (HR) head of a company is unable to conceptualize document and distribute policies and procedure in a simple manner or unable to prepare training plan and get it approved, should we say, there is a problem in the organization or HR manager is incompetent?

The justification for the above observation is clear, either the people in charge of the HRD units have been frustrated by constant budget cuts and lack of support or they are ill equipped to handle the departments. The two are also seriously compounded by the fact that most of the HRD units are seriously disadvantaged in terms of numbers and skills. To put it down frankly, without measurable results and policy guidelines, it is almost impossible to see training as anything else but an expense.

A vital ingredient of training is programs evaluation; Hamblin (1974) defines evaluation as any attempt to obtain information (feedback) on the effects of a training program, and to assess the value of the training in the light of that information 
For successful training, Welch (2005) notes that rigorous, non bureaucratic evaluation system, monitored for integrity is needed in any organization ......it is necessary to create an effective mechanism to reward, recognize and train staff in order to motivate and retain them. The argument here is that training programs are not mounted for the sake of spending the allocated financial vote end, but for those that have gone through thorough scrutiny so as to achieve the desired objective. Welch says to be sure the objective is achieved then there is need for an evaluative mechanism. This is one clear step that is conspicuously absent in public service in Kenya.

Training is seen as a costly venture by some organizations not only because of its financial requirements but also because it means absence of staff from work stations. The Government of Kenya (2005) through the Ministry of State for Public Service (MSPS) has put it that all public servants will be eligible for at least five days training in a year. This is technically meant to ensure that there is training but at the minimum cost possible in terms of money and time. This is not a very unique situation because worldwide consideration reveal as per Derek et all (2005) that only $10 \%$ of organization provided 10 days training per year - the exception to this being Spain where $29 \%$ of the organization provided the 10 days training per year. In all countries the amount of the time for Managerial training was greater than for other groups of employees. In Kenya the situation might be worse, the salvation being that nobody has ever sat to do a quantitative study on how many and actually who attends the five day training in its public service. This on the other hand builds a strong case for this proposed study.

To stamp the justification further, Stewart (2001, April 2) says it is unfortunate organizations sometimes place too much emphasis on the techniques and methods of training and not enough on first defining what the employee should learn in relation to desired job behaviors. In addition, fewer than $50 \%$ of all organizations even try to measure the value of training, and fewer still calculate the return in monetary terms. This is true even of sales training which would seem easy to measure. Just $11 \%$ of the companies attempt to assess the payoffs of training on sales.

Cohen Ed (2007), in his survey on the Leadership without borders found out that the organizations that prosper beyond the frontiers are those that have leadership that pay attention to mentoring, coaching and teaching. People no longer want to work in settings where the leaders are authoritarian micro-managers. They want to work for leaders who empower them; lift a person's performance to a higher standard and build a personality beyond its normal limitations.

With such overwhelming discrepancies and inefficiency from all over the world and even from the best and well known organizations, then the failures in the Ministries in Kenya will just be astounding. But complacency will mean that its normal, attitude which needs to be curtailed for any value to be earned from training. It is therefore very evident that this study will go a long way to seal a yawning gap in the Public Service training.

To succesfully manage to review the literature relevant for this study; following is some brief explanation of concept, re-visiting of theories and a review of empirical works on related areas.

\section{Human Resource Development}

Basically Human Resource Development as a department is a subsystem of an organization that ensures that randomness in training is reduced and learning or behavioral change takes place in a structured format. Its principal objective is to make sure the availability of a skilled, willing, motivated and efficient workforce. In addition to that the individual employees achieve their personal goals and that the organization is ethically and socially responsible to the needs and challenges of the society.

The HRD executive, as Werner and Desimone (2006 page 26) puts it, often serves as an advisor to the chief executive officer and other executives. The outputs of this role include long - range plans and strategies, policies, and budget allocation schedules ... historically during financial difficulties, HRD programs (and HRM, in general) have been a major target of cost-cutting efforts. Unless the HRD executive establishes a clear relationship between HRD expenditure and organizational effectiveness (including profits), HRD programs will not receive the support they need ... the executive must demonstrate the benefit the organization receives by offering such a program. Evaluation data are vital to HRD executive when presenting a case.

Prasad (2007) argues that Human Resource Development refers broadly to the nature and direction of change induced in employees, particularly managerial personnel through the process of training and education. It is the overall development of the competency of the managerial personnel as well as the future requirement.

As per Budhiraja (1977), development is any activity designed to improve the performance of the existing managers and to provide for a planned growth of managers to meet the future organizational requirements. Lall and Sharma (2009) add a similar view that, development is a long - term educational process utilizing a systematic and organized procedure by which managerial personnel learn conceptual and theoretical knowledge for general purpose. 
Bernardin (2007, p.228) defines development as learning opportunities designed to help employees grow. Such opportunities do not have to be limited to improving employees' performance on their current jobs ... the focus of development is on the long term to help employees prepare for future work demands.

From the above definitions a number of issues are evident: Firstly is the fact that development targets the managerial cadre, secondly is that the content of coverage is theoretical and conceptual ideas, thirdly it is for general purpose or a variety of jobs and finally it is a long - term or a strategic action and meant to target the individual employees career growth.

\section{Historical development of Human Resource Management and Development in Kenya}

In the Kenyan workforce, planned and organized labor management and development can be traced to the turn from the $19^{\text {th }}$ to the $20^{\text {th }}$ century. This is well captured by Athanne (2011) in the article titled; "The 4 stages of Human Resource Management Development in Kenya", The first stage was marked by personnel officers getting more responsibilities which included; Staffing, Training and Organizational design. This was the stage of the earliest social scientist which included F.W Taylor, Henry Fayol, Elton Mayo, M.C Gregor and Max Webber.

The second stage of Human Resource Management Development in Kenya covers the period after the second war in which there was scarcity of labor and this led to the rise of trade unions.

Personnel specialists at this time responded by establishing suggesting schemes and establishing developmental interventions to upgrade the available in order to manage the new work environment. This meant establishing joint labor training institutions.

\section{Fig. 2.1 Human Resource Management and Development stages}

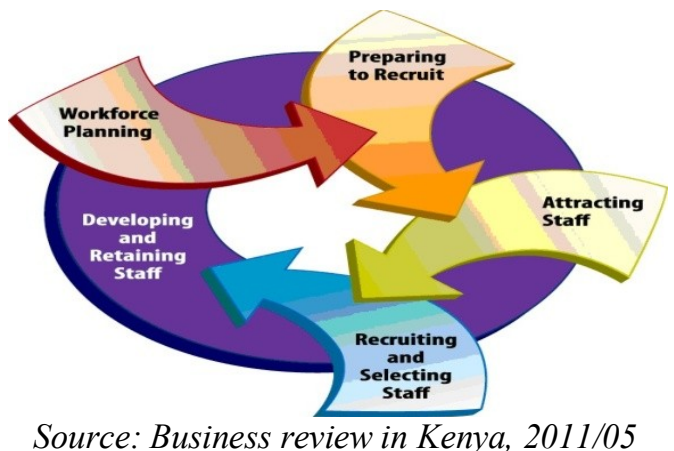

The third stage covers the period 1960's - 1970's. This period was characterized by the emergence of career birth and opportunistic criteria for organization and individual growth. This period saw the development of special techniques for manpower planning and systematically guided HR practices which were concerned with attracting, recruitment, employee development and retention.. It was boosted by the advent of information technology.

The $4^{\text {th }}$ stage of Human Resource Management Development in Kenya covers the period 1980's to present time. In this stage HR is seen as a center that directs efforts towards employee training, employee compensation, satisfying employees' needs and dealing with their problems.

Intense businesses competition has seen the introduction of technologies and computerized information systems to maximize on human resources. Human Resource Management Development in Kenya at the present time is concerned with profit maximization and reduced cost per employee through staff motivation, team work, performance management and appraisal, and empowerment of workers.

\section{Training}

Given the intense pressure to compete, improve quality and customer service, lower costs, private organizations and public alike have all come to view training as a key to their survival and success. Many employers view the skill level of their workforce as a top priority for planning and they suggest continued training for the well being of the organization. As Drucker (1994, p 53-80), a well known management author predicted, the fastest growing industry in the United States will be the continuing education and training of adults due to the replacement of industrial workers with knowledge workers.

International business scholars, Jeffrey Pfeffer and John Veiga (1999), cite training as an essential component of high performance work systems and a source of competitive advantage. As one example they described The Men's Wear house, a specialty retailer of men's tailored business attire that attributes its success ( $400 \%$ increase in stock value) to the emphasis it has placed on training. 
We further need to realize it is not just training that is important but rather focused training depending on the needs of every organization. To justify the study of employee training in the Ministry of Education in Kenya it is necessary to revisit the words of T.V. Rao (2005) as quoted by Neeru (2012), that every nation, industry, sector or organization needs to work out their own management theories and implement practices that work in their context, He was specific that Asian organizations deserve a lot of different treatment and it is high time innovation in terms of program design and management issues were addressed. There is need to think innovatively in designing the curricula, promoting new doctoral programs, research and publications.

Goldstein and Ford (2007, p 1) define training as a systematic acquisition of skills, rules, concepts, or attitudes that result in improved performance in other environment. This therefore means that training programs are planned to produce, for example a more considerate supervisor, a more competent technician, or leaders of complex organizations. It should be noted that even where learning environment is further removed from the job situation, effective training stems from a learning atmosphere systematically designed to produce changes in the working environment.

Bernardin (2007, p 228) defines training as any attempt to improve employee performance on a currently held job or one related to it. This usually means changes in specific knowledge, skills, attitudes, or behaviors. To be effective, training should involve a learning experience, be a planned organizational activity, and be designed in response to identified needs.

Wayne Cascio (2006, p 286), says that, training consists of planned programs designed to improve performance at the individual, group and (or) organizational levels. Improved performance, in turn means that there have been measurable changes in knowledge, skills, attitudes, and (or) social behavior.

\section{Training Needs Assessment}

This is the first phase of training and development and it entails getting to know the gaps in within the organization that can be solved by employee development. These could be poor employee performance or a new challenge that demands a change in the way the organization operates. Identifying the needs involves a scan of the organizations and its environment, relook at job tasks and evaluate employee performance. From that then priorities are drawn, specific training objectives are set and evaluation criteria developed.

\section{Design Phase}

This is the phase that details the plan of action that requires to be done. It involves the following activities; selecting the specific objectives of the program, developing an appropriate lesson plan, developing or acquiring the appropriate material for use, determine who will deliver the content of the program, select the most appropriate methods and finally scheduling the program.

\section{Implementation Phase}

This is the phase at which actual delivery of the program is done. It just involves put into practice what has been planned. It is faced with the implementation challenges like too little time planned for, failure in equipments and machines, noisy or unhealthy environment, conflicts between participants or even failure of trainers to appear. All these challenges require immediate remedy so that the program continues.

\section{Training Evaluation}

To quote Ahmad and Din (2009) in their article on evaluating training and development, they define the process of evaluating training and development as any attempt to obtain information (feedback) on the effects of training program, and to assess the value of the training in the light of that information. They go ahead to add that it is a systematic collection and assessment of information for deciding how best to utilize available training resources in order to achieve organizational goals and objectives. Evaluation tells the trainers which area of the development function requires remedial measures. Welch (2005, page 117), a renowned manager and retired former chairman and C.EO. of General Electric had this to say about evaluation of HR program - after you hired great people, your job becomes managing them into a winning team. Make HR matter, with a cadre of Pastor - parent type at the helm. Ensure people really know how they are doing, with evaluation systems that are honest and real. This has highly been bleached in the public service with evaluation reports written as a matter of routine and tailored to show the juicy side of the story so as to attract more funding.

\section{Perfomance Appraisal}

Performance appraisal has been a nagging problem in work places even in the most developed economies. As Barrack Obama (2006,page 162) notes of teaching in the U.S.A ,in exchange for money, teachers need to become more accountable for their performance and school districts need to have greater ability to get lid of ineffective teachers. So far teachers' unions have resisted the idea of pay for performance, in part because 
it could be disbursed at the whim of a principal. This is a clear indication that there is no clear set system to measure the teachers' performance even in developed economies like the USA. It is worse when it comes to appraising employees in the poor countries mostly because of the poor accounting systems and the social cultural and political lifestyles in such countries.

\section{2: Theoretical literature review}

There is every good reason why this theoretical literature review is of necessity. First and foremost is that it will reveal the gaps in theories, secondly is to figure out if the existing theories are applicable to this study and also help in spotting and ironing out any inconsistencies that may arise.

The first such theory is the Michigan approach which was developed by Fombrun et al. (1984). It stems from the strategic orientation of human resource management such as recruitment, performance appraisal, reward and compensation and development. Battacharyya (2007) states, that this approach argues that an organization's policies in these areas will affect the individual performance of its employees. Human resource research following the Michigan Approach emphasizes organizing and performing all these functions in a way that improves organizational performance. This can be achieved by developing HR practices in line with the organizational strategy.

This is a very vital guide which when critically viewed is either absent or grossly ignored in the case of Kenya's Ministries. The HRD departments have once in a while indulged in programs that are not in line with strategic plans of the Ministries. A part from being wasteful they have resulted in being a de-motivation to the employees.

The second approach is the Harvard approach which was developed and presented by Beer et al. (1984). It assumes that the interest of employees and other stakeholders, together with the situational factors, affect HRM policy choices directly (Boselie 2002). This model recognizes that employees are not resources for the production process only, but are also individuals in themselves. It emphasizes that the central objective of HRM should be to align employees with the organization and the management. This therefore means there has to be a clear and well thought attempt to marry the policies in the strategic vision which will obviously lead to positive human resource outcomes, which not only have an impact on increasing organizational effectiveness but in the long run will also have a cascading effect on their social well being (Battacharyya 2007).

Cascio (2006,p 289), lists nine structural issues that must be addressed if training systems are to reach their full potential...

1. Corporate commitment is lacking and uneven. Most companies spend nothing at all on training. Those that do tend to concentrate on managers, technicians, and professionals, not rank and file workers... in a competitive market-place, the ability to implement rapid changes in products and technologies is often a key requirement to preserve their competitive edge.

2. Aggregate expenditures by business on training are inadequate. Thus the American Society for Training and Development urges business to increase training expenditure to at least 2 percent of their annual payrolls on training - up from the current U.S. industry average of 1.2 percent.

3. Businesses complain that schools award degrees, but degrees are no guarantee that graduates have mastered skills. As a result, business must spend large amounts of money to train workers on basic skills. In a recent survey by AMA (2001), companies reported that, on average 34.1 percent of applicants lack functional workplace literacy - the ability to read instructions, write reports, or do arithmetic at a level adequate to perform common workplace tasks. However only about 6.5 percent of the companies provide remedial training in these basic skills.

4. Poaching trained workers is a major problem for U.S. businesses and provides a strong disincentive for training. Unlike Germany, where local business groups pressure companies not to steal each other's employees, there no such system in the United States. Despite this problem, business may have no choice but to train.

5. Despite the rhetoric about being viewed as an investment, current accounting rules require that it be treated as an expense. Businesses might spend more on training if accounting rules were revised ... training expenditures are seen merely as expenses to be deducted in the year which they are incurred.

6. Government is not providing enough funds for retraining to help workers replaced as result of downsizing... throughout the industrialized world, government leaders are focusing on one of the most corrosive, dangerous trends of the new millennium: the inability of the modern economies to ease the transitions that the young, the poor, and the older workers must make to keep up with the rapid technological changes in the workplace.

7. Businesses, with the help from the governments, need to focus on the 70 percent of non-college graduates who enter the U.S.workforce. At most, 30 percentage of the future workforce will need a college degree. Marriot International Inc. focuses on the remainder. 
8. Employers and schools must develop closer ties. Schools are seen as unresponsive to labor market demands. Business is seen as not communicating its demands to schools. Fortunately this is changing. Sematech, the semiconductor industry association, is working with Maricopa Community College in Phoenix to develop a national curriculum for training entry level manufacturing technicians.

9. Organized labor can help. Unions have developed first - rate apprenticeship programs in a number of crafts. Now they are getting involved in "soft-skills" training as well.

While the above are research findings and experiences of corporate training in the U.S, they are a direct reflection of what happens in most of the countries, developed and otherwise. The Kenyan ministries try as much as they can to pay the little possible on training. Where and when training takes place, it intentionally benefits the top management at the expense of the junior staff and the performance of the entire organization.

To be effective the Ministries have to show commitment to training as part of the corporate culture. They have to do training that is tied to organizational strategies, objectives and linked to bottom line results. The training environment must be "feedback rich" and stress continuous improvement, promote risk taking, and afford opportunities to learn from the successes and failures of decisions. Finally, they must be committed to investing the necessary resources, to provide sufficient time and money for training.

\section{3: $\quad$ Empirical Literature Review}

\section{Training Policies Formulation and Implementation}

Human resource development activities are guided by policies, procedures, circulars and directives but world over, these directions have been assumed. Robert Reich (1991), who recently served as a U.S. Secretary of labor, noted less than $8 \%$ of U.S.firms provided remedial programs for their workers. To say the least that is a pathetic percentage if the remaining $92 \%$ of the workers is expected to be productive all through their working life.

Dayal, Ishwar (1968) as quoted by Devi, Nalini (1996, pg 87) in her study of personnel management practices in South Central Railway contends that 1) training is useful for some and not for all, 2) it can serve some purpose, not all and 3) it is useful provided the firm is capable of using it. He further proposes that 1) if the chief executive and other senior managers are not willing to go for training, their sub-ordinates are unlikely to be willing, 2) if the company is not used to experimentation, it is not likely that the participant will use his learning to sufficient advantage and 3) if the person is not capable of learning, he is unlikely to make the best use of the facilities open to him.

As Pervaiz (Feb 2012) found out in her study on the impact of training on employee turnover, Training can have a huge impact on the company's profitability position as there are several potential training costs that companies may incur. But once a training program is completed, employees' productivity is expected to increase. This will benefit both the company, due to an increase in worker output and productivity, and to the worker, as the increase in output should translate into higher wages and opportunities for career advancement. Ponnam (2004) examined the impact of training on first generation entrepreneurs in Tripura and found that the training programs have a positive effect on increasing the production and bring positive change and develop the regions economically, but for maximization training required some policy and regulation structures.

Ravindra et al (2005) have emphasized on applying a systematic approach to employee training practices both for Indian and international organizations in order to achieve effective training and enhancement level of "innovation training - development - action - sustainable growth" with the true concern for meaningful development of human society as a whole and in order to ensure the successful implementation of the training strategies.

Goldstein and Ford (2007, p 7) reveals that a study by Olson (1994) produced data that were consistent with the above perceptions. Taking data from the Nation Household Education Survey, he found in the 1990s that about $25 \%$ of the employed U.S. workforce participated in some form of training during any 12 -month period. However, that training was unevenly distributed in the workforce and mainly assisted the more skilled workers in the upper portions of the wage distribution ... this data reinforce the concerns expressed by Reich, who feels the future workplace will need the abilities of all our workers in order to have the skilled workforce required by modern technology.

Goldstein and Ford (2007 pg 2), when reviewing a study on National Center on Educational Quality of the Workforce, found out that a $10 \%$ increase in the educational attainment of a company's workforce resulted in $8.6 \%$ increase in productivity while a $10 \%$ increase in value of capital stock such as tools and buildings only resulted in a $3.4 \%$ increase in productivity. This gives clear evidence why human resource development is vital to any organization-private or public.

Dr. P.N.Rastogi's (2001) study discusses the nature and rationale of knowledge management and intellectual capital as a new defining paradigm of business leadership, which stems from their role in shaping and enhancing a firm's market power and performance. He asserts that, without effective firms there is no effective leadership and without knowledge management and intellectual capital there are no effective firms. 
Vasanti Srinivasan (2005) concludes after his study and emphasizes on the need to assess the relationship between performance management systems and other HR systems like compensation, career development, rewards and recognition systems.

The above is testimony to the fact that there is necessity to plan well about the human resource base of organizations. Most of the public institutions do not show much interest in this because it is rare that they are called upon to account for the consequences of their human resource practice activities. The HRD activities should be those that give the organization competitive advantage in the future. Policies on training and development should be those that address the weaknesses of the workforce in terms of improving their performance.

Quoting Moses, T (2006), T.V. Rao in one of his articles observes that it is the high time probably to give to give a new life to HRD at least in some organizations by abolishing the HRD roles and creating a new agenda for change and competence building through Chief Learning Managers (CLM) and Chief Knowledge Managers (CKM). At least a title change could bring back the lost focus on learning.

Narayan et al (2006) in their article "ready for the next leap?" have articulated the views of many Indian CEOs that apart from innovations and infrastructure, the real change that is required in Indian manufacturing companies is in the Human Resources and the skills base. In the new environment, managers who are and able to focus on global customers' requirement will come out the winners. This will require the ability to get or upgrade the skills that can address to the needs of the diverse customer base.

\section{Training Needs Analysis}

Frances et al (2000) were of the view that training is a major investment, hence training should be focused - providing the right training for the right people at the right cost is the key to success for training professionals. Training needs analysis and training evaluation are vital tools in ensuring that this objective is achieved. So business needs should be the driving force for training systems. In the Ministry of Education there are times that these principles have not been adhered to.

Ratan Reddy (2001) in his research work emphasized that the objective of training should go expand beyond the application of on-the-job skills training. He highlighted the need for designing and developing educational and developmental programs to enable employees to learn for possible future needs. The study examined, analyzed and suggested the introduction of developmental programs to help individuals prepare for higher levels of responsibility and increase productivity and output.

Robert D. Gatewood (2001) is of the opinion that both the ability of an employee and his contribution to the organization can at least partially be controlled by the organization. Ability is a function of two organizational practices, selection and training. An organization either finds individuals with the ability to do the work or it teaches those abilities to them. The effort that is exerted by the employee is a function of the organizations numerous practices to motivate employees. However he asserts that all motivation effort assumes that employees have the proper abilities to actually perform the job. Training is therefore a critical activity for an organization. It is one of the only two ways of ensuring that employees have abilities to do their work.

Mathew Guthridge, et al (2008) are of the view that organizations like to promote the idea that employees are their biggest sources which give them competitive advantage, yet most of them are not working towards the challenge of investing adequate attention and resources in finding and making the right employees for the right job, motivating them to contribute and retaining capable retaining capable employees. Although the importance is acknowledged by the executives, adequate attention has not been paid to address issues appropriately.

The above issues are a clear testimony to what is happening to the Ministry of Education in Kenya. Once recruitment is done no other attention is paid to hone the skills of the employees for maximum production. Any training and development ventures lack the accuracy of the problems they intend to address.

\section{Induction and Orientation}

Induction has to be about how the employee is welcomed to the organization: how they establish their relationship with colleagues and with supervisors; how they engage with the overall direction and vision of the organization and how they see their role within the structure. How the individual responds to this and performs will then be a matter of assessment during the course of work.

It is very clear that those employees who make a decision to leave the organization, a huge number of them, makes that decision during the settling down phase. This is all because orientation and socialization was poorly handled from the start. To quote Jones (March 2012) "How this relationship develops during the formative period in an organization will influence the future for that employee. In my experience, the contribution made by an employee and the extent of their commitment to the organization are strongly related to the way in which they were treated in the early phase of their career. To the extent that employees join 
organizations and leave before managers know their problem is a direct reflection of the failure of the induction and on-boarding process".

Leaving on organization should never be viewed at its face value. Pervaiz (2012), says that according to the Saratoga Institute, which specializes in quantitative human resources measurement systems, the average company loses about $\$ 1$ million for every 10 professional employees who leave. This has led to corporations to think more on retention, for instance in 2002, American Businesses invested nearly $\$ 54.2$ billion on corporate training according to Training Magazine. Some of this investment has been shown to impact retention of employees.

Orientation and socialization programs should start immediately an employee has been hired and long before the reporting day. Michele Adamson (2009) on her study on how Blue Cross Blue Shield Alabama attracts and retains her employees, says that between the time a candidate accepts the position and day one, they are acclimatized to the culture, and provided with the resources they needed complete their processing during pre-boarding. This means that recruiters and HR staff can focus more on making face-to-face orientations about what it means to work here versus filling out forms.

Ministries sometimes handle the orientation as an event rather than a process. The event typically comprises a brief overview of the organization by one or more senior manager, an explanation of the policies and procedures which have to be followed, and an appointment with HR to fill in various forms so that an email address can be established and payroll knows who the next of kin is. This kind of orientation does not make meaningful use to the settling down process.

\section{Employee mentoring, counseling, coaching and succession management}

For any organization to prosper then the future to be leaders have to be identified and molded towards that end. This may not be a very common practice with the Ministry of Education in Kenya. HRD practices should be in such a way that such talent is identified before it is lost to competition.

The study by Glenn Rowe, et al (2005), examines the impact of leader succession on organizational performance. They argue that it takes time for a new leader to bring out change in the organizational performance. The focus was to examine if all leader successions affects performance and if leaders do matter. The results demonstrated supports for the fact that there should be organizational learning and those senior officers should be given time to be familiar with the organization in order to develop organizational specific skills, knowledge and values. Once this is done then succession will obviously have a positive impact on the organizational performance.

A good example is what Kenya power (2012) do to develop their staff; "Kenya Power has a staff complement of over 7,000 employees. We recruit and aim at retaining highly motivated professional staff in order to meet our corporate goals.

Great importance is attached to ensuring that employees have requisite competencies to perform their work and also realize their potential through regular staff training and development programs. On-the-job training is the foundation upon which all other training must depend, and we acknowledge the role our experienced employees play in training their colleagues.

Management staffs sign performance contracts which form the basis of their annual appraisals". This is a clear testimony from one of the top corporate organizations in Kenya. It reveals various HRD practices like; employee re-training, training needs assessment, employee coaching and mentoring, and performance management by performance contracting and appraisal.

\section{Performance Management}

According to Ronnie Malcolm as quoted by Kholiet et all (2008), performance management is a planned and systematic approach to managing the performance of individuals ensuring their personal development and contribution towards organizational goals.

Armstrong et al (2004) defined performance management as a process that contributes to the effective management of individuals and teams in order to achieve high level of organizational performance. When results and objectives are not achieved it all boils down to the performance management structure that is supposed to propel the organization towards the results. Charles, L. (1984, pg 91), states that the poorly defined work structure is not just an architectural problem but a philosophical one as well, something is wrong with the design. He suggests that the superior and sub-ordinate would understand what is expected of them in the job if all performance data would be linked clearly to pre-established criteria found in the proper appraisal format.

It is true organizations spend a lot of money to measure and report financial performance and effectiveness of sales, marketing and supply chain but these systems rarely measure and report the effectiveness of people processes in the organization. Hence organizations have no insight into their employees' success, skills gap and learning needs that exist within the organization or how they affect the performance and 
productivity of the organization. This is a very true reflection of what is happening in the Kenyan public service and no exceptional to the Ministry of Education.

Michael George (2005) says that firms have begun to rely on their performance management data to assist them in making major business decisions and shying away from systems requiring extensive customization preferring instead, off-the-shelf solutions that provide high value and are easy use along with consulting services that ensure successful implementation. Further year round performance management and goal alignment are becoming standard expectations for many organizations. Organizations are learning that they have to manage employee performance aggressively in order to identify top performers and develop an optimally functional work force.

Robert Bacal (2010) in his articles on Performance Management, Performance Appraisal and Employee Reviews summarizes that employee training and development activities are intended to improve performance. Unfortunately, most of the most training and development activities fail in this respect because they are thrown at problems that are ill-defined and are improperly indentified. Since the point of both training and development is to improve performance it makes sense to use them together so that the performance management process ends up telling you what kind of training and development will be most effective in a given situation.

A large organization that has reaped the benefits of training is The Ritz-Carlton Hotel which manages thirty six luxury hotels worldwide with over 17,000 employees and sales of more than $\$ 1$ billion. In 1999 it became the first and only service industry to receive MalcomBaldridge National Quality award in the service category. This can be attributed to the fact that the hotel uses training as a key to employee retention. Every first-year manager at Ritz-Carlton received between 250 and 310 hours of training, designed to align with its strategic plan and organizational objectives.

Bushan (2002) is of the opinion that as a system for development of personnel in an organization, HRD is generally brought about through a bunch of subsystems all of which are meant to focus on development of an individual and groups constituting the social system of the organization. The subsystems of HRD include training and development, performance and potential appraisal, reinforcement, organizational development, career planning and development of HR planning. All these though to some degree present in the public service in Kenya a lot of effort is needed to stream line them for attainment of desired training goals.

\section{Training Programs Evaluation}

The importance of evaluation of training programs cannot be assumed, but this has not made even the best of the best organizations to put a lot of emphases on them. For example, the survey by Ralphs and Stephen (1986) of the Fortune 500 firms about evaluation indicate that most evaluations (86\%) consist of trainee reactions that are written at the end of the course.

Relatively few efforts are made to collect information concerning performance changes by means of follow-up on the job, which is when both the trainee and the organization could discover whether the programs are achieving the desired results and when the evaluation could provide clues to the modifications necessary to enable the program to work. When this evaluation is not done in such companies, it leaves one wondering if this has been accepted as the norm.

Augustus, Gerald Jnr. (1994), in his dissertation to examine the effect of performance appraisal training on ratees' attitudes and behaviours had results that indicated that participation in ratee focused performance appraisal training led to significance increase for a number of desirable behavioral, procedural and substantive outcomes. These included feedback seeking behaviours, understanding of appraisal process, satisfaction with the performance appraisal and motivation to improve performance throughout the appraisal cycle.

Greer (2002) has stressed the need to have economic rationale for investment in training. He was of the view that employers generally invest in or pay part of the cost of specific training because employees cannot readily transfer such skills to other employers. Employers recoup their investment after employees complete training by paying employees only part of the revenue derived from their increased productivity, thus he was of the view that every training program in these days of high competition and increased cost should justify the investment made on it.

Saari et al.'s (1988) survey of 600 firms found similar results, for example, these companies reported that executive MBA programs were the most expensive management-training approach averaging about $\$ 14,000$ for each participant, yet $42 \%$ of the companies reported that they did not conduct any evaluation of their effectiveness, similarly, only $27 \%$ of the companies surveyed had a formal procedure designed to conduct needs assessments in order to determine the specific training and the education needs of their managers.

Devi, N.(1996, pg 106), points out that performance appraisal has traditionally been used as a mechanism of controlling employees through salary administration, reward administration, promotions and disciplinary action. Each employee is rated confidentially by one or more senior officers annually for his performance on certain dimensions and the confidential ratings are handled by personnel department. In most 
cases the employee does not know how is performance has been rated by his superiors. This leaves the employees not aware about their strength and weaknesses in relation to their capabilities.

Bolar, M. (1970, pg 34-44), opined that evaluation systems be used, not merely to indentify training needs, but also as a measure of effectiveness of development programs. The effectiveness of training can be meaningfully evaluated through the company's system and both should be viewed together.

Mihir, K.B. (1988), covered managerial appraisal practices in large and medium sized business organizes in both private and public sectors in India (excluding Government departments or departmental undertakings and non-profit organizations). The findings were that there was a growing use of formal appraisal system. Most Indian organizations were using appraisal for multiple objectives, i.e. salary progression, promotion, training and development, placement and transfer. He made an attempt to provide guidelines for developing and introducing a performance appraisal system in organizations.

Rao, T.V. (1984) conducted a survey of appraisal practices in 34 private sector and 11 public sector organizations. He observed that Indian organizations are quite varied from almost no appraisal to a sophisticated multipurpose, multi component based appraisal system.

Basically, training systems are viewed by both organization and individuals as a positive step in providing skills and opportunities. For all to benefit, the training system need to be more carefully designed and more carefully evaluated to ensure that they are meeting the expectations of both the organizations and the individual trainees.

Anil Kumar Saxena (1993), as quoted in Arshad, H (2008-pg 27), in his study on the "Role of Evaluation of Training in Designing Training Programs in Institutions of Government, Private and Public Sector and Banking Institutions in Andhra Pradesh", found that the training systems is weak; evaluation of training in many organizations are unscientific and do not indicate transfer of learning on the job, and therefore suggested that the training evaluation system could be improved by simulated learning exercises, group discussions, video films and observation techniques.

Singh, Somorendro (2011-pg 12-13), in his article on Education in Manipur, notes that lack of evaluation and proper policy guide lines can lead to a lot of expenditure that is not warranted. He says the centre appears to take keen interest and actively encourages the present practice of lifeless construction as "development", ignoring education and other basic necessities of the people of the state. This approach to "development" proves to be highly lucrative for the ruling classes given the lack of accountability and prevalence of the law of the jungle.

Hall, B and A. Wasynczuk (2011), summarizes that, performance reviews are not just for doing layoffs and promotions the right way ... well executed evaluations give a company the data it requires to develop talent. Employees need to know what they are doing well and what they are doing poorly so that they can improve ... rather than viewing appraisal as a compliance exercise, perceive them as a chance to shape a developing talent.

\section{4: Gaps in Research}

A number of related studies have been done throughout the world but all have failed to address the current HRD problem areas targeted by this study. Most of them have treated HRD practices as any other HRM issue which is not the case. More others have dwelt on the private Corporations world over and completely left out the public sector. A few that have targeted the public sector, have concentrated on the specific technical areas of that public sector domain. The specific area of HRD practices in the Ministry of Education is completely un-explored and the reason why I put my focus on it. Any time Ministry of Education is mentioned, what comes to mind is the technical role of the Ministry but not the developmental aspect of the staff that run the Ministry. Highlighting on some of these studies will open the gap that the research study is struggling to cover.

Mehul (2013), in the study titled; "Perceived QWL among textile workers", he studied 175 workers in the Textile Hub of Gujarat State-Surat. He used a 5- point scale questionnaire to collect and analyzed data using chi-squared test.

He found out that workers were dissatisfied with how the following were handled; opportunities of career growth in the industry, social integration in the work place, and opportunities to use and develop human capacities which finally led to a perceived low QWL among the workers.

He forwarded the following suggestions and recommendations; mandatory provision of health related and safe working conditions, disposal of waste and effluence and ventilations. The organization should stimulate a feeling of sense of community by allowing social groupings at work place. He felt there should be more opportunities for staff promotion and growth. There should be an opportunity for interaction among workers and superiors like working in team groups. Finally he advocated for enhancement of the workers skills and capacities.

Naveen (2011), in his study titled: Service quality perspective and satisfaction in private banking: an empirical evidence using SERQUAL model in Rajasthan, India, done between June 2010 to June 2011 
investigated 450 banking customers on what contributes to their satisfaction. Although his study on customers he ended up make serious suggestions on the staff training and development.He used factor analysis; Alpha reliability testing and regression analysis and he found that apart from product satisfaction, pre-sale service, post-sale service and office service contributes a lot to the perception of satisfaction by customers.

He suggested changes like; review of policies to ensure short time by customers which meant retraining their staff on best service delivery and customer care. He further suggested that infrastructural facilities like offices, office space, parking, seat arrangements, and provisions of drinking water, fans and toilets should be improved to capture customers. He emphasized that the staff development should be key in the changes because it is them to implement and improve the customer satisfaction.

A study on the effectiveness of performance contracts was done by Ombonyo (2007) in a study entitled; Performance contracts and performance of public sector in Kenya: a case study of National Housing Corporation in which he examined whether performance contracts improved performance in the public sector. A sample of 100 employees was selected across the board from 376 employees. Data was collected using a semistructured questionnaire which was analyzed and presented by use of charts, graphs and bar graphs. Additional data was got from government reports and NHC annual reports and manuals.

The research revealed the factors that hinder the effectiveness of the Performance Contracts in the Public Sector included poor leadership, lack of government support, poor organizational structures, low budgetary provisions, poor control, monitoring and evaluation, inadequate training and development policies, lack of internal communications, inadequate technology and poor sensitization programs. It was also established that Performance Contracts were linked to other management systems like employment Contract of service, Performance appraisals, the corporate strategic plan and the overall budget. However it was noted that Performance Contracts were not linked to rewards and salaries, which is very vital in the successful implementation of the Performance Contracts. It was also established from the study that the Performance Contracts had influenced new technology and skills in the Public Sector. Innovation and creativity had been encouraged due to the introduction of Performance Contracts.

The survey revealed that Performance Contracts improved efficiency and effectiveness in the corporation where 87 percent of the respondent indicates that Performance Contracts had improved efficiency and effectiveness. The study revealed that Performance Contract did not influence profits and productivity in the corporation.

The survey recommended the areas to be improved for Performance Contracts to be effective are adequate preparation before introducing Performance Contracts, allow employees to set their targets and set a leadership structure that allows management flexibility in decision making.

May be, the study to have come closest is that by Nzoma, Nthenya (2011) in the study titled "Effectiveness of employee training and development in Kenya: a case study of Teachers Service Commission". In the study 140 employees were sampled from 2400 employees of TSC through stratified random sampling technique. Data was collected using a structured questionnaire and analyzed using averages, percentages and frequencies through SPSS computer package.

The study sought to determine the impact of training and development on effective performance of employees. The study found that training and development impacts positively on productivity, increased efficiency, and improved quality of work, improved morale and team work. This study only falls short in that it looks at a narrower range of performance dimensions; leaving out issues like target setting, risk taking, communication, nationalism, integrity and transparency.

Lwiki, Nelson (2007), in his study on the effect of staff training and development on performance and the relevance of training programs offered to the staff of Co-operative College, he studied 20 management staff, 20 other staff members and every $6^{\text {th }}$ of the in-service students. He collected primary and secondary data and found out that the college had staff training programs and strategies that needed to be restructured and constantly reviewed to keep pace with the socio-technological challenges. He realized that $90 \%$ of the programs were relevant to the staff and they had a positive impact on performance of staff and increased their efficiency, effectiveness and promoted the corporate image of the College.

However, the research established that the training opportunities available were not spelt out, there was inadequate resource allocation and policy statement was missing. He recommended that there should be a systematic approach to training and put in place a training policy to guide training in the college.

A study by Kiiru (2011), on the impact of training and development on performance of staff in the audit sector collected primary data by use of questionnaires to be filled by staff of Deloitte and Touche Company in its offices in Westlands, Nairobi. Secondary data was also collected from past records and SPSS was used to analyze the data and produces descriptive statistics like mean, percentages, and proportions.

From the findings the researcher found out that there is a positive relationship between training and development and the performance of staff in the organizations. He suggested that training and development is a major ingredient in employees' performance hence should be enhanced. 
Another study that focused on training and development and its impact on productivity was done in Nzoia Sugar Company of Western Kenya by Wanyama Robert (2012) who administered questionnaires to 87 out of 300 management and supervisory staff of the company. This was through stratified sampling. A purposive sampling technique was employed to administer interview schedule to all training officers in the organization.

Quantitative and qualitative methods were used to analyze data and tables, pie charts, graphs, percentages were used for presentation. The study looked at key factors that affect training and development and came out with the following; training budget, training needs assessment, age employees, experience of employees, training methods, quality of trainers and the company's training policies. The study recommended that these factors need to be given great emphases to ensure that training and developmental programs were beneficial to Nzoia Sugar Company and the sugar industry in general.

Messah and Kamencu (2011), embarked on a study on the effects of performance appraisal systems on employees performance, specifically doing their study in the tea factories in Meru County of Kenya. They did a descriptive research which sampled 70 respondents from a possible 348 by employing stratified random sampling and picking $20 \%$ from every stratum. A questionnaire was used to collect primary data. Data analyses and presentation was done to reveal the relationship between performance appraisal tools $\mathrm{n}$ performance.

The results revealed that competence assessment and development, management by objectives, performance based pay, and employee training all had a positive impact on employees' performance in the Kenya Tea Development Agency. Employee training, performance based pay and management by objective were ranked very highly by respondents to "a great extent". The factor competence assessment and development was moderately ranked hence also substantial. Correlation and multiple regression also revealed that employee training, performance based pay and management by objective were the main factors that had a huge impact on employee performance in KTDA.

\title{
3.1: Introduction
}

\section{Research Methodology}

In this section the procedure and strategies that were used to carry out the study are discussed. These are research population under study, research design, target population, sample and sampling procedure and research instruments. It is basically a theoretical display on how research was carried out.

\section{2: Research Design}

The research design adopted was descriptive research design. Kothari (2004) explains that descriptive research study is that study that attempts to assess a group, individual or organization then describe its characteristics. This therefore looks the best design to follow since in the final analysis the study should be able to make suggestions on how to improve the HRD practices in the Ministry of Education so that training of employees can be improved.

\section{3: Research Population}

The research covered the employees of the Ministry of Education in the Republic of Kenya. These are a total of 5,009 employees spread throughout the country and classified in seven departments or directorates. These are; Basic Education, Secondary Education, Adult Education and Continued Learning, Quality Assurance and Standards, Policy and Planning, Support Services and Field services.

\section{4: Location of Study}

Research was carried out in five provinces in the Republic of Kenya. These were randomly sampled from the total of eight provinces. These were; Nairobi Province, Central Province, Coast Province, Eastern Province and Rift Valley Province. In the Province one County was sampled for study and these were;

\author{
Nairobi Province - \\ Central Province - \\ Ministry Head Quarters \\ Coast Province - \\ Nyeri County \\ Eastern Province - \\ Mombasa County \\ Rift Valley Province \\ Meru County \\ Western Province- \\ -Uasin Gishu County \\ North Eastern Province- \\ Nyanza Province - \\ These locations gave a very representative scan of the whole nation.
}




\section{5: Target Population}

The study targeted all the employees of the Ministry but sampled in three strata and distributed in all the departments in a proportional bases. The three strata by which sample were divided were; higher management level, middle level management and lower level staff.

\section{6: Scope and Sampling Design}

The study covered the Ministry of Education in the Republic of Kenya. It was conducted in 5 of the 8 provinces Kenya. The Provinces were randomly picked then one county was picked at random to represent the Province. In the county all the staff available during the day of data collection made up the sample population. The sampling design was therefore probabilistic and convenient sampling combining simple random and stratified random sampling and then finally a full census in the counties that were sampled.

The study picked respondents from all the directorates of the Ministry namely: Basic Education, Secondary Education, Quality Assurance and Standards, Adult Education and Continued Learning, Policy and planning, Support services and Field Services.

The Ministry has a total of 5,009 employees who made up the population of study. The employees were further stratified into three levels namely:

\section{Junior Staff (Job Group A-H)}

Middle Management (Job Group J-N)

Senior Management (Job Group P-V)

The respondents were got from the sampled counties from all the departments of the Ministry and in all the levels. Except for the Ministry head quarters all the other counties had all the available staff filling the questionnaires.

The sample size calculation as per the online Creative Research System and Raosoft sample size calculator, a population of around 5,000 assuming a 95\% confidence level and 5\% confidence interval (margin of error) a sample size of 357 is sufficient. But to take care of non-response the study targeted 440 respondents but finally it is 404 respondents who handed in their questionnaires.

Table 3.1 Population and Sample Space

\begin{tabular}{|l|l|l|l|}
\hline Sampling / Employees & Population size & $\begin{array}{l}\text { Targeted } \\
\text { sample size }\end{array}$ & Working Sample size \\
\hline Junior Staff & 3106 & 245 & 123 \\
\hline Mid-Mangmt & 1771 & 155 & 154 \\
\hline Snr. Mangmnt & 132 & 40 & 87 \\
\hline Total & $\mathbf{5 , 0 0 9}$ & $\mathbf{4 4 0}$ & $\mathbf{3 6 4}$ \\
\hline
\end{tabular}

\section{7: Data Collection}

Data was collected by use of a questionnaire which was distributed to all the sampled employees to get the implementation index of the various HRD practices in the Ministry of Education.

\section{8: Data Analysis and Presentation}

Data was analyzed by use of averages, percentages, linear correlation, and Analysis of Variance (ANOVA). SPSS and MS excel packages were be used.

Data presentation was done by use of tables, pie charts, line graphs and bar graphs.

\section{9: Data Collection Instruments}

For the collection of data a questionnaire was administered to the employees of the Ministry to get their opinion on implementation of HRD practices. Introduction letters, research visit schedules, maps, record sheet and tables were of great assistance during the data collection exercise.

\subsection{0: $\quad$ Reliability of Questionnaires}

To test for Reliability of the research questionnaires the coefficient alpha, or Cronbach's alpha was used and it revealed the following results:

Table 3.2: Case Processing Summary for questionnaire 1

\begin{tabular}{|ll|l|l|}
\hline & & $\mathrm{N}$ & $\%$ \\
\hline Cases & Valid & 364 & 100.0 \\
& Excluded(a) & 0 & .0 \\
& Total & 364 & 100.0 \\
\hline
\end{tabular}

A List wise deletion based on all variables in the procedure. 
Table 3.3: Reliability Statistics for questionnaire 1

\begin{tabular}{|l|l|}
\hline Cronbach's Alpha & N of Items \\
\hline .878 & 28 \\
\hline
\end{tabular}

The reliability test for Questionnaire 1 shows a Cronbach's alpha value of $\mathbf{0 . 8 7 8}$ which reveals high reliability rating of the Questionnaire.

\subsection{1: Areas of Future Study}

Due to pressure of time and resources it is not basically possible to conclusively study this topic. It is therefore prudent to site some areas that are very much related to the topic but that need to be studied in future. These are namely:

a) Assessment of performance evaluation tools used in the Ministries. This is in view of how much the tools are used in the Ministries and their accuracy in actual measurement of the performance of the employees.

b) Comparative study of training policies and procedures in every Ministry. This will make a distinction as to which specific Ministries are not following the training procedures and policies.

\section{1: Introduction}

\section{Data Analysis and Intepretation}

This chapter gives the analysis and interpretation of the data collected from the Ministry employees on implementation of various HRD practices. The data was collected by use of a questionnaire filled by all the cadres of employees representatively picked from all the departments of the Ministry. The questionnaire captured the employees' opinion on the HRD practices as they are practiced and implemented in the Ministry. A number of items were used to get response on each practice.

Statistical Package for Social Science (SPSS) was basically used for data analysis. Averages, percentages, frequency tabulation, standard deviation, and Analysis of Variance (ANOVA) were some of the tools that were used for analysis. SPSS output tables were used for data presentation. An explanatory text accompanied every table for elaboration sake. There is a frequency table foe every questionnaire item and an ANOVA table for every hypothesis tested for acceptance or rejection.

\section{Descriptive Statistics on Questionnaire items based on HRD practices}

The tables below give a summary of the employees' responses on various items that tested the level of implementation of the HRD practices. They show the mean implementation index out of a maximum of 5 and the standard deviation, which showed how varied the employees' opinions were.

Table 4.1: Induction and Orientation

\begin{tabular}{|l|r|r|r|r|r|}
\hline & N & Minimum & Maximum & Mean & Std. Deviation \\
\hline $\begin{array}{l}\text { Any documented Induction } \\
\text { Program }\end{array}$ & 364 & 1 & 5 & 2.53 & .980 \\
\hline $\begin{array}{l}\text { Information on Culture and } \\
\text { Procedures }\end{array}$ & 364 & 1 & 5 & 2.80 & .978 \\
\hline Time taken before Induction & 364 & 1 & 5 & 2.33 & 1.048 \\
\hline Valid N (list wise) & 364 & & & \\
\hline
\end{tabular}

The three items show a low implantation index of the induction and orientation as a practice. There is revelation that little documentation done and the timing of induction and orientation is also poor. The standard deviation values are also huge showing discrepancy in opinions.

Table 4.2: Counseling and Coaching

\begin{tabular}{|l|r|r|r|r|r|}
\hline & N & \multicolumn{1}{|c|}{ Minimum } & Maximum & Mean & Std. Deviation \\
\hline $\begin{array}{l}\text { Any help to deal with } \\
\text { Personal Problems }\end{array}$ & 364 & 1 & 5 & 2.37 & .982 \\
\hline $\begin{array}{l}\text { Employees attached to senior } \\
\text { staff }\end{array}$ & 364 & 1 & 5 & 2.85 & .974 \\
\hline $\begin{array}{l}\text { Senior staff consults and } \\
\text { shares with junior staff }\end{array}$ & 364 & 1 & 5 & 2.87 & 1.060 \\
\hline Valid N (list wise) & 364 & & & \\
\hline
\end{tabular}

The three items reveal a low implementation index of counseling and coaching as a practice in the Ministry. It is clear that personal problems are poorly addressed in the Ministry. Attachment and consultation by senior staff is also low. The standard deviations reveal varied opinions. 
Table 4.3: Training Needs Assessment

\begin{tabular}{|l|r|r|r|r|r|}
\hline & N & Minimum & Maximum & Mean & Std. Deviation \\
\hline $\begin{array}{l}\text { Views of whole staff when } \\
\text { making TNA }\end{array}$ & 364 & 1 & 5 & 2.62 & 1.015 \\
\hline $\begin{array}{l}\text { Consideration of Individual } \\
\text { and Ministerial Needs }\end{array}$ & 364 & 1 & 5 & 2.87 & .894 \\
\hline Fairness of MTC & 364 & 1 & 5 & 2.83 & 1.065 \\
\hline Relevance of courses offered & 364 & 1 & 5 & 3.42 & 1.013 \\
\hline Valid N (list wise) & 364 & & & \\
\hline
\end{tabular}

Except the item on relevance of courses attended, the other items show a below average index of implementation. The standard deviation values show a wide span of opinions.

Table 4.4: Training Policies Formulation

\begin{tabular}{|l|r|r|r|r|r|}
\hline & N & \multicolumn{1}{|c|}{ Minimum } & Maximum & Mean & Std. Deviation \\
\hline $\begin{array}{l}\text { Every Employee is Trained for } \\
\text { at least five days }\end{array}$ & 364 & 1 & 5 & 2.09 & 1.067 \\
\hline $\begin{array}{l}\text { Policies are formulated by a } \\
\text { Team or Committee }\end{array}$ & 364 & 1 & 5 & 2.99 & .945 \\
\hline $\begin{array}{l}\text { Policies are realistic and } \\
\text { employee sensitive }\end{array}$ & 364 & 1 & 5 & 2.99 & .923 \\
\hline $\begin{array}{l}\text { Policies allow employees to } \\
\text { make decision }\end{array}$ & 364 & 1 & 5 & 2.60 & 1.027 \\
\hline Valid N (list wise) & 364 & & & & \\
\hline
\end{tabular}

The item on 5 say training per employee shows a very implementation index. Items on team of formulators and realistic policies show about average level of implementation while employees' chance to make decisions is low. Standard deviations again reveal diverse opinions from employees.

Table 4.5: Career Guidance and Development

\begin{tabular}{|l|r|r|r|r|r|}
\hline & N & Minimum & Maximum & Mean & Std. Deviation \\
\hline $\begin{array}{l}\text { Mechanism to Indentify and } \\
\text { place talents }\end{array}$ & 364 & 1 & 5 & 2.36 & .944 \\
\hline $\begin{array}{l}\text { Courses that lead to career } \\
\text { Growth }\end{array}$ & 364 & 1 & 5 & 2.53 & .931 \\
\hline $\begin{array}{l}\text { Opportunities for } \\
\text { Professional Development }\end{array}$ & 364 & 1 & 5 & 2.76 & 1.089 \\
\hline Valid N (list wise) & 364 & & & \\
\hline
\end{tabular}

The items portray this has one of the worst implemented practices. It reveals a poor mechanism of identifying talent and preparation of employees' growth career wise. Standard deviation shows huge figures hence a wide variation of opinions.

Table 4.6: Evaluation of Training Programs

\begin{tabular}{|l|r|r|r|r|r|}
\hline & N & Minimum & Maximum & Mean & Std. Deviation \\
\hline $\begin{array}{l}\text { Trainees give views before } \\
\text { Training program starts }\end{array}$ & 364 & 1 & 5 & 2.88 & 1.098 \\
\hline $\begin{array}{l}\text { Trainees give post training } \\
\text { comments }\end{array}$ & 364 & 1 & 5 & 3.32 & 1.025 \\
\hline $\begin{array}{l}\text { Job performance feedback is } \\
\text { sought }\end{array}$ & 364 & 1 & 5 & 2.70 & .976 \\
\hline Valid N (list wise) & 364 & & & \\
\hline
\end{tabular}

Post training evaluation has an above average implementation while pre training and job performance evaluation are below average rank in implementation. Once again standard deviation is high showing varied opinions.

Table 4.7: Performance Appraisal and Relevance of Training

\begin{tabular}{|l|r|r|r|r|r|}
\hline & N & Minimum & Maximum & Mean & Std. Deviation \\
\hline $\begin{array}{l}\text { Training is focused on skills } \\
\text { deficiencies }\end{array}$ & 364 & 1 & 5 & 3.37 & .946 \\
\hline
\end{tabular}




\begin{tabular}{|c|c|c|c|c|c|}
\hline $\begin{array}{l}\text { Training helps introduce cost } \\
\text { saving activities }\end{array}$ & 364 & 1 & 5 & 2.89 & .943 \\
\hline $\begin{array}{l}\text { Training is beneficial for } \\
\text { promotion and progression }\end{array}$ & 364 & 1 & 5 & 3.65 & .923 \\
\hline Training fosters team work & 364 & 1 & 5 & 3.58 & .937 \\
\hline $\begin{array}{l}\text { Training fosters better } \\
\text { communication and interpersonal } \\
\text { relations }\end{array}$ & 364 & 2 & 5 & 3.61 & .804 \\
\hline Increase in performa Appraisal & 364 & 1 & 5 & 3.76 & .889 \\
\hline $\begin{array}{l}\text { Increase in effort and time to } \\
\text { work }\end{array}$ & 364 & 1 & 5 & 2.99 & .872 \\
\hline $\begin{array}{l}\text { Reward system for excellent } \\
\text { performance }\end{array}$ & 364 & 1 & 5 & 2.11 & 1.058 \\
\hline Valid N (list wise) & 364 & & & & \\
\hline
\end{tabular}

The items reveal that performance appraisal is implemented at an index above average in most of the items. Reward system for excellent performance has a very low implantation index. Standard deviation reveals wide employee opinions.

\section{2: Hypotheses Testing} rejection.

The section applies various data analysis tools to test the various research hypothesis for acceptance all

Table 4.8: Descriptive Statistics on HRD practices

\begin{tabular}{|l|l|l|l|}
\hline & Mean & Std. Deviation & Analysis N \\
\hline Induction and Orientation & 2.5549 & .75314 & 364 \\
\hline Counseling and Coaching & 2.7134 & .80362 & 364 \\
\hline Training Needs Assessment & 2.9334 & .70992 & 364 \\
\hline Training Policies Formulation & 2.6662 & .66638 & 364 \\
\hline $\begin{array}{l}\text { Career Guidance and } \\
\text { Development Training }\end{array}$ & 2.5495 & .76681 & 364 \\
\hline $\begin{array}{l}\text { Evaluation of } \\
\text { Programs appraisal and }\end{array}$ & 3.2466 & .78943 & 364 \\
\hline $\begin{array}{l}\text { Performance A698 } \\
\text { Relevance of Training }\end{array}$ & .59272 & 364 \\
\hline
\end{tabular}

The mean scores of the HRD practices implementation in the Ministry reveal that it is only Performance Appraisal as a practice, that score above a mean of 3.00 out of 5.00, registering a mean of 3.25. Training Needs Assessment and Training Programs Evaluation follow closely at 2.93 and 2.97 respectively. Others show an average score with Induction and Orientation and Career Guidance and development registering the lowest at 2.55 .

All the practices reveal a case of high standard deviation of more than 0.75 , except performance appraisal and training policies formulation which have 0.59 and 0.67 respectively. This is an implication of the fact that the responses were varied and it is only these two that have a lower variation.

Table 4.9: ANOVA test result on the significance of the difference between the implementation of various practices on average

\begin{tabular}{|c|c|c|c|c|c|c|}
\hline & & $\begin{array}{l}\text { Sum of } \\
\text { Squares }\end{array}$ & df & Mean Square & $\mathbf{F}$ & Sig. \\
\hline \multirow{3}{*}{$\begin{array}{l}\text { Induction } \\
\text { Orientation }\end{array}$} & Between Groups & 185.407 & 168 & 1.104 & 10.501 & .000 \\
\hline & Within Groups & 20.494 & 195 & .105 & & \\
\hline & Total & 205.901 & 363 & & & \\
\hline \multirow{2}{*}{$\begin{array}{l}\text { Counseling } \\
\text { Coaching }\end{array}$} & Between Groups & 206.736 & 168 & 1.231 & 8.665 & .000 \\
\hline & Within Groups & 27.692 & 195 & .142 & & \\
\hline
\end{tabular}


The Doom of Employees' Training in Public Service - A Case Study of Ministry of Education in Kenya

\begin{tabular}{|c|c|c|c|c|c|c|}
\hline & Total & 234.428 & 363 & & & \\
\hline \multirow{3}{*}{$\begin{array}{l}\text { Training } \\
\text { Assessment }\end{array}$} & Between Groups & 158.898 & 168 & .946 & 7.669 & .000 \\
\hline & Within Groups & 24.049 & 195 & .123 & & \\
\hline & Total & 182.947 & 363 & & & \\
\hline \multirow{3}{*}{$\begin{array}{l}\text { Training } \\
\text { Formulation }\end{array}$} & Between Groups & 146.857 & 168 & .874 & 11.889 & .000 \\
\hline & Within Groups & 14.337 & 195 & .074 & & \\
\hline & Total & 161.194 & 363 & & & \\
\hline \multirow{3}{*}{$\begin{array}{l}\text { Career Guidance and } \\
\text { Development }\end{array}$} & Between Groups & 197.644 & 168 & 1.176 & 14.520 & .000 \\
\hline & Within Groups & 15.799 & 195 & .081 & & \\
\hline & Total & 213.443 & 363 & & & \\
\hline \multirow{3}{*}{$\begin{array}{l}\text { Evaluation of Training } \\
\text { Programs }\end{array}$} & Between Groups & 193.581 & 168 & 1.152 & 6.883 & .000 \\
\hline & Within Groups & 32.643 & 195 & .167 & & \\
\hline & Total & 226.223 & 363 & & & \\
\hline \multirow{3}{*}{$\begin{array}{l}\text { Performance Appraisal } \\
\text { and Relevance of } \\
\text { Training }\end{array}$} & Between Groups & 113.923 & 168 & .678 & 9.720 & .000 \\
\hline & Within Groups & 13.604 & 195 & .070 & & \\
\hline & Total & 127.527 & 363 & & & \\
\hline
\end{tabular}

The hypotheses that "there is no significance difference in the way the HRD practices are implemented" is REJECTED because all the practices have an F calling for rejection at 0.05 level. This means that on average all the practices are implemented in very different ways, therefore giving us reason to accept the alternate hypothesis that "there is a significant difference in the way HRD practices are implemented in the Ministry".

HRD Practices as they were implemented within various departments

Table 4.9: Descriptive Statistics showing HRD practices by department

\begin{tabular}{|c|c|c|c|c|c|c|}
\hline & & $\mathbf{N}$ & Mean & Std. Deviation & Std. Error & Maximum \\
\hline \multirow[t]{8}{*}{$\begin{array}{l}\text { Induction } \\
\text { Orientation }\end{array}$} & Administration & 143 & 2.3939 & .84812 & .07092 & 4.67 \\
\hline & Q.A.S. & 84 & 2.7698 & .59443 & .06486 & 3.67 \\
\hline & $\mathbf{P} \& \mathbf{P}$ & 15 & 2.7111 & .30516 & .07879 & 3.33 \\
\hline & Secondary & 34 & 2.5980 & .64500 & .11062 & 4.33 \\
\hline & Basic & 19 & 2.5088 & .80407 & .18447 & 4.33 \\
\hline & Adult and Cont. & 44 & 2.7348 & .89089 & .13431 & 5.00 \\
\hline & Field Services & 25 & 2.3200 & .33993 & .06799 & 3.00 \\
\hline & Total & 364 & 2.5549 & .75314 & .03948 & 5.00 \\
\hline \multirow[t]{8}{*}{$\begin{array}{l}\text { Counseling and } \\
\text { Coaching }\end{array}$} & Administration & 143 & 2.6014 & .74981 & .06270 & 4.33 \\
\hline & Q.A.S. & 84 & 2.6190 & .68282 & .07450 & 4.33 \\
\hline & $\mathbf{P \& P}$ & 15 & 2.9778 & .69541 & .17955 & 5.00 \\
\hline & Secondary & 34 & 2.9314 & 1.15406 & .19792 & 8.00 \\
\hline & Basic & 19 & 3.0702 & 1.00357 & .23023 & 5.00 \\
\hline & Adult and Cont. & 44 & 2.8939 & .72523 & .10933 & 4.33 \\
\hline & Field Services & 25 & 2.6267 & .79536 & .15907 & 5.00 \\
\hline & Total & 364 & 2.7134 & .80362 & .04212 & 8.00 \\
\hline \multirow[t]{2}{*}{$\begin{array}{ll}\text { Training } & \text { Needs } \\
\text { Assessment } & \end{array}$} & Administration & 143 & 2.7220 & .62243 & .05205 & 4.50 \\
\hline & Q.A.S. & 84 & 2.9345 & .69542 & .07588 & 4.50 \\
\hline
\end{tabular}


The Doom of Employees' Training in Public Service - A Case Study of Ministry of Education in Kenya

\begin{tabular}{|c|c|c|c|c|c|c|}
\hline & $\mathbf{P} \& \mathbf{P}$ & 15 & 3.6333 & .57373 & .14814 & 4.50 \\
\hline & Secondary & 34 & 3.1985 & .55657 & .09545 & 4.50 \\
\hline & Basic & 19 & 3.3684 & .75631 & .17351 & 4.50 \\
\hline & Adult and Cont. & 44 & 3.1705 & .63514 & .09575 & 5.00 \\
\hline & Field Services & 25 & 2.6100 & .92444 & .18489 & 4.50 \\
\hline & Total & 364 & 2.9334 & .70992 & .03721 & 5.00 \\
\hline \multirow[t]{8}{*}{$\begin{array}{l}\text { Training Policies } \\
\text { Formulation }\end{array}$} & Administration & 143 & 2.5629 & .68528 & .05731 & 4.50 \\
\hline & Q.A.S. & 84 & 2.8423 & .60343 & .06584 & 4.50 \\
\hline & P\&P & 15 & 2.8167 & .39491 & .10196 & 3.50 \\
\hline & Secondary & 34 & 2.6985 & .62091 & .10649 & 4.50 \\
\hline & Basic & 19 & 2.8816 & .68399 & .15692 & 4.50 \\
\hline & Adult and Cont. & 44 & 2.7614 & .65360 & .09853 & 5.00 \\
\hline & Field Services & 25 & 2.2000 & .68845 & .13769 & 3.25 \\
\hline & Total & 364 & 2.6662 & .66638 & .03493 & 5.00 \\
\hline \multirow[t]{8}{*}{$\begin{array}{l}\text { Career Guidance and } \\
\text { Development }\end{array}$} & Administration & 143 & 2.4126 & .75987 & .06354 & 4.67 \\
\hline & Q.A.S. & 84 & 2.6310 & .80994 & .08837 & 5.00 \\
\hline & $\mathbf{P \& P}$ & 15 & 2.3778 & .85325 & .22031 & 4.33 \\
\hline & Secondary & 34 & 2.6078 & .61666 & .10576 & 4.33 \\
\hline & Basic & 19 & 2.8772 & .77945 & .17882 & 4.67 \\
\hline & Adult and Cont. & 44 & 2.6515 & .78406 & .11820 & 5.00 \\
\hline & Field Services & 25 & 2.6533 & .65603 & .13121 & 4.33 \\
\hline & Total & 364 & 2.5495 & .76681 & .04019 & 5.00 \\
\hline \multirow[t]{8}{*}{$\begin{array}{l}\text { Evaluation of } \\
\text { Training Programs }\end{array}$} & Administration & 143 & 2.9580 & .88180 & .07374 & 5.00 \\
\hline & Q.A.S. & 84 & 2.8889 & .59298 & .06470 & 4.00 \\
\hline & $\mathbf{P \& P}$ & 15 & 3.2444 & .82102 & .21199 & 4.67 \\
\hline & Secondary & 34 & 3.2647 & .80311 & .13773 & 4.67 \\
\hline & Basic & 19 & 3.1228 & .80285 & .18419 & 4.67 \\
\hline & Adult and Cont. & 44 & 2.8712 & .65579 & .09886 & 4.67 \\
\hline & Field Services & 25 & 2.8000 & .90267 & .18053 & 4.67 \\
\hline & Total & 364 & 2.9698 & .78943 & .04138 & 5.00 \\
\hline \multirow[t]{8}{*}{$\begin{array}{l}\text { Performance } \\
\text { Appraisal }\end{array}$} & Administration & 143 & 3.2273 & .49260 & .04119 & 4.75 \\
\hline & Q.A.S. & 84 & 3.1324 & .58126 & .06342 & 4.13 \\
\hline & $\mathbf{P \& P}$ & 15 & 3.5667 & .44034 & .11370 & 4.50 \\
\hline & Secondary & 34 & 3.3199 & .66443 & .11395 & 4.50 \\
\hline & Basic & 19 & 3.5197 & .65254 & .14970 & 4.75 \\
\hline & Adult and Cont. & 44 & 3.4318 & .57973 & .08740 & 4.75 \\
\hline & Field Services & 25 & 2.9150 & .84373 & .16875 & 4.75 \\
\hline & Total & 364 & 3.2466 & .59272 & .03107 & 4.75 \\
\hline
\end{tabular}

The table 4.10, below is an SPSS ANOVA output to show test results for testing the difference between HRD practices implementation and employees departments.

Ho: "There is no significant influence of the department in the way HRD practices are implemented in the Ministry".

Table 4.10: ANOVA test for HRD practices against Departments 
The Doom of Employees' Training in Public Service - A Case Study of Ministry of Education in Kenya

\begin{tabular}{|c|c|c|c|c|c|c|}
\hline & & $\begin{array}{l}\text { Sum of } \\
\text { Squares }\end{array}$ & Df & Mean Square & $\mathbf{F}$ & Sig. \\
\hline \multirow{3}{*}{$\begin{array}{l}\text { Induction } \\
\text { Orientation }\end{array}$} & Between Groups & 10.860 & 6 & 1.810 & 3.313 & .003 \\
\hline & Within Groups & 195.041 & 357 & .546 & & \\
\hline & Total & 205.901 & 363 & & & \\
\hline \multirow{3}{*}{$\begin{array}{l}\text { Counseling } \\
\text { Coaching }\end{array}$} & Between Groups & 9.246 & 6 & 1.541 & 2.443 & .025 \\
\hline & Within Groups & 225.182 & 357 & .631 & & \\
\hline & Total & 234.428 & 363 & & & \\
\hline \multirow{3}{*}{$\begin{array}{l}\text { Training } \\
\text { Assessment }\end{array}$} & Between Groups & 24.811 & 6 & 4.135 & 9.335 & .000 \\
\hline & Within Groups & 158.136 & 357 & .443 & & \\
\hline & Total & 182.947 & 363 & & & \\
\hline \multirow{3}{*}{$\begin{array}{l}\text { Training } \\
\text { Formulation }\end{array}$} & Between Groups & 11.217 & 6 & 1.870 & 4.450 & .000 \\
\hline & Within Groups & 149.977 & 357 & .420 & & \\
\hline & Total & 161.194 & 363 & & & \\
\hline \multirow{3}{*}{$\begin{array}{l}\text { Career Guidance and } \\
\text { Development }\end{array}$} & Between Groups & 6.564 & 6 & 1.094 & 1.888 & .082 \\
\hline & Within Groups & 206.880 & 357 & .579 & & \\
\hline & Total & 213.443 & 363 & & & \\
\hline \multirow{3}{*}{$\begin{array}{l}\text { Evaluation of Training } \\
\text { Programs }\end{array}$} & Between Groups & 6.251 & 6 & 1.042 & 1.691 & .122 \\
\hline & Within Groups & 219.972 & 357 & .616 & & \\
\hline & Total & 226.223 & 363 & & & \\
\hline \multirow{3}{*}{$\begin{array}{l}\text { Performance Appraisal } \\
\text { and Relevance of } \\
\text { Training }\end{array}$} & Between Groups & 8.543 & 6 & 1.424 & 4.272 & .000 \\
\hline & Within Groups & 118.984 & 357 & .333 & & \\
\hline & Total & 127.527 & 363 & & & \\
\hline
\end{tabular}

Table 4.11: Summary of test Results of HRD practices against Departments

\begin{tabular}{|l|l|l|l|}
\hline HRD PRACTICES & F-Value & Critical Value & Comment \\
\hline Induction and Orientation & $\mathbf{3 . 3 1 3}$ & $\mathbf{2 . 1 0}$ & REJECTED \\
\hline Counseling and Coaching & $\mathbf{2 . 4 4 3}$ & $\mathbf{2 . 1 0}$ & REJECTED \\
\hline Training Needs Assessment & $\mathbf{9 . 3 3 5}$ & $\mathbf{2 . 1 0}$ & REJECTED \\
\hline Training Policies Formulation & $\mathbf{4 . 4 5 0}$ & $\mathbf{2 . 1 0}$ & REJECTED \\
\hline Career Guidance and Development & $\mathbf{1 . 8 8 8}$ & $\mathbf{2 . 1 0}$ & ACCEPTED \\
\hline Evaluation of Training Programs & $\mathbf{1 . 6 9 1}$ & $\mathbf{2 . 1 0}$ & ACCEPTED \\
\hline Performance Appraisal & $\mathbf{4 . 2 7 2}$ & $\mathbf{2 . 1 0}$ & REJECTED \\
\hline
\end{tabular}

Viewed against a critical value of $\mathbf{2 . 1 0}$ two of the practices: - Career Guidance and development, and Training Programs Evaluation have the hypothesis ACCEPTED, thus; "There is no significant influence of the department in the way HRD practices are implemented in the Ministry". Therefore these are the only two practices where departments are not a consideration when these HRD practices are preferred to staff.

In the other five practices the $\mathrm{F}$ values are greater than the critical value of $\mathbf{2 . 1 0}$ hence the hypothesis is REJECTED, thus; "There is a significant influence of the department in the way the HRD practices are implemented in Ministry". This implies some department could be getting undue advantage towards training programs while others are getting intentional disadvantage.

HRD practices as they were implemented across various levels of experience

Table 4.12: HRD Practices as they were implemented in relation to years of Experience

\begin{tabular}{|c|c|c|c|c|c|c|c|}
\hline & & $\mathbf{N}$ & Mean & Std. Deviation & Std. Error & Minimum & Maximum \\
\hline \multirow[t]{5}{*}{$\begin{array}{l}\text { Induction } \\
\text { Orientation }\end{array}$} & less than 5 & 47 & 2.3901 & .93592 & .13652 & 1.33 & 4.67 \\
\hline & $5-15$ & 62 & 2.5376 & .80380 & .10208 & 1.33 & 4.67 \\
\hline & $16-25$ & 183 & 2.6794 & .64844 & .04793 & 1.00 & 5.00 \\
\hline & above 25 & 72 & 2.3611 & .77672 & .09154 & 1.00 & 3.67 \\
\hline & Total & 364 & 2.5549 & .75314 & .03948 & 1.00 & 5.00 \\
\hline
\end{tabular}


The Doom of Employees' Training in Public Service - A Case Study of Ministry of Education in Kenya

\begin{tabular}{|c|c|c|c|c|c|c|c|}
\hline $\begin{array}{l}\text { Counseling and } \\
\text { Coaching }\end{array}$ & less than 5 & 47 & 2.4043 & .80138 & .11689 & 1.00 & 4.33 \\
\hline & $5-15$ & 62 & 2.5323 & .94755 & .12034 & 1.33 & 8.00 \\
\hline & $16-25$ & 183 & 2.8342 & .76705 & .05670 & 1.33 & 5.00 \\
\hline & above 25 & 72 & 2.7639 & .68846 & .08114 & 1.33 & 3.67 \\
\hline & Total & 364 & 2.7134 & .80362 & .04212 & 1.00 & 8.00 \\
\hline \multirow[t]{5}{*}{$\begin{array}{ll}\text { Training } & \text { Needs } \\
\text { Assessment } & \\
\end{array}$} & less than 5 & 47 & 2.5957 & .63749 & .09299 & 1.75 & 4.00 \\
\hline & $5-15$ & 62 & 2.5444 & .71507 & .09081 & 1.25 & 4.50 \\
\hline & $16-25$ & 183 & 3.0560 & .66398 & .04908 & 1.75 & 5.00 \\
\hline & above 25 & 72 & 3.1771 & .66135 & .07794 & 2.00 & 4.25 \\
\hline & Total & 364 & 2.9334 & .70992 & .03721 & 1.25 & 5.00 \\
\hline \multirow[t]{5}{*}{$\begin{array}{ll}\text { Training } & \text { Policies } \\
\text { Formulation } & \end{array}$} & less than 5 & 47 & 2.5904 & .59075 & .08617 & 1.50 & 4.25 \\
\hline & $5-15$ & 62 & 2.7056 & .87018 & .11051 & 1.00 & 4.50 \\
\hline & $16-25$ & 183 & 2.6284 & .64772 & .04788 & 1.25 & 5.00 \\
\hline & above 25 & 72 & 2.7778 & .54475 & .06420 & 2.00 & 3.75 \\
\hline & Total & 364 & 2.6662 & .66638 & .03493 & 1.00 & 5.00 \\
\hline \multirow[t]{5}{*}{$\begin{array}{l}\text { Career Guidance and } \\
\text { Development }\end{array}$} & less than 5 & 47 & 2.4113 & .83467 & .12175 & 1.00 & 4.67 \\
\hline & $5-15$ & 62 & 2.6720 & .80185 & .10183 & 1.67 & 4.33 \\
\hline & $16-25$ & 183 & 2.4863 & .76693 & .05669 & 1.33 & 5.00 \\
\hline & above 25 & 72 & 2.6944 & .66136 & .07794 & 1.67 & 4.00 \\
\hline & Total & 364 & 2.5495 & .76681 & .04019 & 1.00 & 5.00 \\
\hline \multirow[t]{5}{*}{$\begin{array}{l}\text { Evaluation of Training } \\
\text { Programs }\end{array}$} & less than 5 & 47 & 2.8582 & 1.09179 & .15925 & 1.00 & 5.00 \\
\hline & $5-15$ & 62 & 2.9677 & .79550 & .10103 & 1.33 & 4.67 \\
\hline & $16-25$ & 183 & 3.0474 & .72219 & .05339 & 1.33 & 4.67 \\
\hline & above 25 & 72 & 2.8472 & .70308 & .08286 & 2.00 & 4.67 \\
\hline & Total & 364 & 2.9698 & .78943 & .04138 & 1.00 & 5.00 \\
\hline \multirow{5}{*}{$\begin{array}{l}\text { Performance Appraisal } \\
\text { and Relevance of } \\
\text { Training }\end{array}$} & less than 5 & 47 & 3.2633 & .54188 & .07904 & 2.25 & 4.75 \\
\hline & $5-15$ & 62 & 3.1492 & .62103 & .07887 & 1.75 & 4.63 \\
\hline & $16-25$ & 183 & 3.2261 & .57479 & .04249 & 1.50 & 4.75 \\
\hline & above 25 & 72 & 3.3715 & .63425 & .07475 & 1.88 & 4.75 \\
\hline & Total & 364 & 3.2466 & .59272 & .03107 & 1.50 & 4.75 \\
\hline
\end{tabular}

The table 4.12, reveals that Induction and Orientation as a practice is low among the employees with less than 5 years experience and those with over 25 years of experience. It is highest among those in the bracket of $16-25$ years of experience.

Counseling and Coaching is lowest among those employees with less than 5 years experience and highest among those between $16-25$ years and those above 25 years in experience.

Training Needs Assessment is low among employees with less than 15 years of experience and high among those with more than 16 years of experience. The difference is on the range of half a digit.

Training Policies Formulation shows a similar trend where the employees with less than 5 years experience with an implementation index of 2.59 and the highest being among the employees with over 25 years experience at 2.78 . 
Career Guidance and Development is low among the less than 5 years experience and those in the bracket of 16 -25 years experience while it shows a slight increase among those between $5-15$ years and employees above 25 years experience. A mean of 2.55 is quite a low index.

Training Programs Evaluation shows one of the highest implementation indices. All the experience groups show an even index with less than 5 years at 2.87 and the $16-25$ years in experience having an index of 3.05. The mean is at 2.97 out of 5.00.

Performance Appraisal, as a practice is the best in implementation index with a mean of 3.25. All the experience levels show a high score ranging from 3.26 among the employees with less than 5 years experience to 3.37 among those with over 25 years of experience. Employees with 5 - 15 years experience report a slightly lower index of 3.15 .

Hypotheses test for HRD Practices against the years of experience of employees

Table 4.13: ANOVA test for HRD practices against years of Experience

\begin{tabular}{|c|c|c|c|c|c|c|}
\hline & & $\begin{array}{l}\text { Sum of } \\
\text { Squares }\end{array}$ & Df & Mean Square & $\mathbf{F}$ & Sig. \\
\hline \multirow[t]{3}{*}{$\begin{array}{l}\text { Induction and } \\
\text { Orientation }\end{array}$} & Between Groups & 6.837 & 3 & 2.279 & 4.121 & .007 \\
\hline & Within Groups & 199.064 & 360 & .553 & & \\
\hline & Total & 205.901 & 363 & & & \\
\hline \multirow[t]{3}{*}{$\begin{array}{l}\text { Counseling and } \\
\text { Coaching }\end{array}$} & Between Groups & 9.382 & 3 & 3.127 & 5.003 & .002 \\
\hline & Within Groups & 225.046 & 360 & .625 & & \\
\hline & Total & 234.428 & 363 & & & \\
\hline \multirow[t]{3}{*}{$\begin{array}{l}\text { Training Needs } \\
\text { Assessment }\end{array}$} & Between Groups & 21.769 & 3 & 7.256 & 16.208 & .000 \\
\hline & Within Groups & 161.178 & 360 & .448 & & \\
\hline & Total & 182.947 & 363 & & & \\
\hline \multirow{3}{*}{$\begin{array}{l}\text { Training } \\
\text { Policies } \\
\text { Formulation }\end{array}$} & Between Groups & 1.524 & 3 & .508 & 1.145 & .331 \\
\hline & Within Groups & 159.670 & 360 & .444 & & \\
\hline & Total & 161.194 & 363 & & & \\
\hline \multirow{3}{*}{$\begin{array}{l}\text { Career } \\
\text { Guidance and } \\
\text { Development }\end{array}$} & Between Groups & 4.071 & 3 & 1.357 & 2.333 & .074 \\
\hline & Within Groups & 209.372 & 360 & .582 & & \\
\hline & Total & 213.443 & 363 & & & \\
\hline \multirow{3}{*}{$\begin{array}{l}\text { Evaluation of } \\
\text { Training } \\
\text { Programs }\end{array}$} & Between Groups & 2.769 & 3 & .923 & 1.487 & .218 \\
\hline & Within Groups & 223.454 & 360 & .621 & & \\
\hline & Total & 226.223 & 363 & & & \\
\hline \multirow[t]{3}{*}{$\begin{array}{l}\text { Performance } \\
\text { Appraisal and } \\
\text { Relevance of } \\
\text { Training }\end{array}$} & Between Groups & 1.802 & 3 & .601 & 1.720 & .162 \\
\hline & Within Groups & 125.725 & 360 & .349 & & \\
\hline & Total & 127.527 & 363 & & & \\
\hline
\end{tabular}

Table 4.14: Summary of test Results of HRD practices against Experience

\begin{tabular}{|l|l|l|l|}
\hline HRD PRACTICES & F-Value & Critical Value & Comment \\
\hline Induction and Orientation & $\mathbf{4 . 1 2 1}$ & $\mathbf{2 . 6 0}$ & REJECTED \\
\hline Counseling and Coaching & $\mathbf{5 . 0 0 3}$ & $\mathbf{2 . 6 0}$ & REJECTED \\
\hline Training Needs Assessment & $\mathbf{1 6 . 2 0 8}$ & $\mathbf{2 . 6 0}$ & REJECTED \\
\hline Training Policies Formulation & $\mathbf{1 . 1 4 5}$ & $\mathbf{2 . 6 0}$ & ACCEPTED \\
\hline Career Guidance and Development & $\mathbf{2 . 3 3 3}$ & $\mathbf{2 . 6 0}$ & ACCEPTED \\
\hline Evaluation of Training Programs & $\mathbf{1 . 4 8 7}$ & $\mathbf{2 . 6 0}$ & ACCEPTED \\
\hline Performance Appraisal & $\mathbf{1 . 7 2 0}$ & $\mathbf{2 . 6 0}$ & ACCEPTED \\
\hline
\end{tabular}

Ho: There is no significant influence of the years of employees' experience in the way the HRD practices are implemented in the Ministry of Education in Kenya.

The following four HRD practices; Training Policies Formulation, Career Guidance and Development, Evaluation of Training Programs and Performance Appraisal show an F value which calls for acceptance of the 
above null hypothesis, implying that there is no significant influence of the years of experience in how one accesses the various HRD practices. This implies that an employee's work experience is not a significant consideration when training is being preferred to employees.

While, three other practices; Induction and Orientation, Counseling and Coaching and Training Needs Assessment show an $\mathrm{F}$ value that is greater than the critical value of $\mathbf{2 . 6 0}$ hence calls for rejection of the null hypothesis hence accept the alternate hypothesis;

H1: There is a significant influence of the years of Employees' Experience on the way HRD Practices are implemented. This has a clear implication that years of employees experience are taken as a significant consideration when selecting employees for various training programs.

HRD Practices implementation when analyzed against the employees' Job Level

Table 4.15: The Mean Occurrence of the HRD Practices against Job Level

\begin{tabular}{|c|c|c|c|c|c|}
\hline & & $\mathbf{N}$ & Mean & Std. Deviation & Std. Error \\
\hline \multirow[t]{4}{*}{ Induction and Orientation } & Lower Level & 123 & 2.3902 & .87747 & .07912 \\
\hline & Middle level & 154 & 2.5541 & .69881 & .05631 \\
\hline & Senior Management & 87 & 2.7893 & .58206 & .06240 \\
\hline & Total & 364 & 2.5549 & .75314 & .03948 \\
\hline \multirow[t]{4}{*}{ Counseling and Coaching } & Lower Level & 123 & 2.5528 & .81853 & .07380 \\
\hline & Middle level & 154 & 2.8442 & .87004 & .07011 \\
\hline & Senior Management & 87 & 2.7088 & .60104 & .06444 \\
\hline & Total & 364 & 2.7134 & .80362 & .04212 \\
\hline \multirow[t]{4}{*}{$\begin{array}{l}\text { Training } \\
\text { Assessment }\end{array}$} & Lower Level & 123 & 2.6789 & .55212 & .04978 \\
\hline & Middle level & 154 & 3.0536 & .81798 & .06591 \\
\hline & Senior Management & 87 & 3.0805 & .60340 & .06469 \\
\hline & Total & 364 & 2.9334 & .70992 & .03721 \\
\hline \multirow[t]{4}{*}{$\begin{array}{l}\text { Training } \\
\text { Formulation }\end{array}$} & Lower Level & 123 & 2.5671 & .66919 & .06034 \\
\hline & Middle level & 154 & 2.6899 & .74648 & .06015 \\
\hline & Senior Management & 87 & 2.7644 & .47212 & .05062 \\
\hline & Total & 364 & 2.6662 & .66638 & .03493 \\
\hline \multirow[t]{4}{*}{$\begin{array}{l}\text { Career Guidance and } \\
\text { Development }\end{array}$} & Lower Level & 123 & 2.4201 & .77746 & .07010 \\
\hline & Middle level & 154 & 2.6623 & .83929 & .06763 \\
\hline & Senior Management & 87 & 2.5326 & .56937 & .06104 \\
\hline & Total & 364 & 2.5495 & .76681 & .04019 \\
\hline \multirow[t]{4}{*}{$\begin{array}{l}\text { Evaluation of Training } \\
\text { Programs }\end{array}$} & Lower Level & 123 & 2.9458 & .87920 & .07927 \\
\hline & Middle level & 154 & 3.0216 & .77607 & .06254 \\
\hline & Senior Management & 87 & 2.9119 & .67334 & .07219 \\
\hline & Total & 364 & 2.9698 & .78943 & .04138 \\
\hline \multirow[t]{4}{*}{$\begin{array}{l}\text { Performance Appraisal } \\
\text { and Relevance of Training }\end{array}$} & Lower Level & 123 & 3.2663 & .48937 & .04413 \\
\hline & Middle level & 154 & 3.2606 & .67002 & .05399 \\
\hline & Senior Management & 87 & 3.1940 & .58374 & .06258 \\
\hline & Total & 364 & 3.2466 & .59272 & .03107 \\
\hline
\end{tabular}

Induction and Orientation reveals a low prevalence level with employees' opinion showing that low level staff have a mean of 2.39 and senior staff highest at 2.79 out of a maximum of 5.00 . The total average of the practice is 2.55 .

Coaching and counseling is lowest to the lower level at 2.55 followed by senior management at 2.71, with the middle level management highest at 2.84. The total average of 2.71 is still a low score out of 5.00.

Training Needs Assessment is at 2.68 among the lower level staff and close to 3.1 among the middle level and senior level management.

Training Policies Formulation is low among the lower level staff at 2.57 and increases marginally to senior level management at 2.76. The total average is at 2.67 which can be classified as a low score.

Career Guidance and counseling is poorly implemented across all the Job Levels with lower level with a score of 2.42, middle level at 2.66 and senior management at 2.53 . 
Training Programs Evaluation shows an improved implementation score with low level staff scoring 2.94, senior level at 2.91 and middle level marginally higher at 3.02. Though an improvement compared to the others, as a practice it is also on average low at 2.97 .

Performance Appraisal is the highest ranking Practice at an average of 3.25. The lower level highest ranked at 3.27 followed by middle level at 3.26 and senior management at 3.19.

Testing the hypotheses on HRD Practices analyzed against the Employees' Job Level

Table 4.16: ANOVA test on HRD practices against Employees' Job Level

\begin{tabular}{|c|c|c|c|c|c|c|}
\hline & & $\begin{array}{l}\text { Sum of } \\
\text { Squares }\end{array}$ & Df & Mean Square & $\mathbf{F}$ & Sig. \\
\hline \multirow[t]{3}{*}{$\begin{array}{l}\text { Induction and } \\
\text { Orientation }\end{array}$} & Between Groups & 8.114 & 2 & 4.057 & 7.405 & .001 \\
\hline & Within Groups & 197.787 & 361 & .548 & & \\
\hline & Total & 205.901 & 363 & & & \\
\hline \multirow[t]{3}{*}{$\begin{array}{l}\text { Counseling and } \\
\text { Coaching }\end{array}$} & Between Groups & 5.805 & 2 & 2.903 & 4.583 & .011 \\
\hline & Within Groups & 228.623 & 361 & .633 & & \\
\hline & Total & 234.428 & 363 & & & \\
\hline \multirow[t]{3}{*}{$\begin{array}{l}\text { Training Needs } \\
\text { Assessment }\end{array}$} & Between Groups & 12.075 & 2 & 6.037 & 12.755 & .000 \\
\hline & Within Groups & 170.872 & 361 & .473 & & \\
\hline & Total & 182.947 & 363 & & & \\
\hline \multirow{3}{*}{$\begin{array}{l}\text { Training } \\
\text { Policies } \\
\text { Formulation }\end{array}$} & Between Groups & 2.134 & 2 & 1.067 & 2.421 & .090 \\
\hline & Within Groups & 159.061 & 361 & .441 & & \\
\hline & Total & 161.194 & 363 & & & \\
\hline \multirow{3}{*}{$\begin{array}{l}\text { Career } \\
\text { Guidance and } \\
\text { Development }\end{array}$} & Between Groups & 4.047 & 2 & 2.023 & 3.488 & .032 \\
\hline & Within Groups & 209.396 & 361 & .580 & & \\
\hline & Total & 213.443 & 363 & & & \\
\hline \multirow[t]{3}{*}{$\begin{array}{l}\text { Evaluation of } \\
\text { Training } \\
\text { Programs }\end{array}$} & Between Groups & .777 & 2 & .388 & .622 & .538 \\
\hline & Within Groups & 225.446 & 361 & .625 & & \\
\hline & Total & 226.223 & 363 & & & \\
\hline \multirow[t]{3}{*}{$\begin{array}{l}\text { Performance } \\
\text { Appraisal and } \\
\text { Relevance of } \\
\text { Training }\end{array}$} & Between Groups & .319 & 2 & .159 & .452 & .637 \\
\hline & Within Groups & 127.208 & 361 & .352 & & \\
\hline & Total & 127.527 & 363 & & & \\
\hline
\end{tabular}

The Hypotheses under test is:

Ho: "There is no significant influence of the job level in the way HRD Practices are implemented in the Ministry of Education in Kenya".

Table 4.17: Summary of test Results of HRD practices against Employees' Job Level

\begin{tabular}{|l|l|l|l|}
\hline HRD PRACTICES & F-Value & Critical Value & Comment \\
\hline Induction and Orientation & $\mathbf{7 . 4 0 5}$ & $\mathbf{3 . 0 0 0}$ & REJECTED \\
\hline Counseling and Coaching & $\mathbf{4 . 5 8 3}$ & $\mathbf{3 . 0 0 0}$ & REJECTED \\
\hline Training Needs Assessment & $\mathbf{1 2 . 7 5 5}$ & $\mathbf{3 . 0 0 0}$ & REJECTED \\
\hline Training Policies Formulation & $\mathbf{2 . 4 2 1}$ & $\mathbf{3 . 0 0 0}$ & ACCEPTED \\
\hline Career Guidance and Development & $\mathbf{3 . 4 8 8}$ & $\mathbf{3 . 0 0 0}$ & REJECTED \\
\hline Evaluation of Training Programs & $\mathbf{0 . 6 2 2}$ & $\mathbf{3 . 0 0 0}$ & ACCEPTED \\
\hline Performance Appraisal & $\mathbf{0 . 4 5 2}$ & $\mathbf{3 . 0 0 0}$ & ACCEPTED \\
\hline
\end{tabular}

Three of the seven HRD Practices that is; performance appraisal, evaluation of training programs, and training policies formulation have the null hypothesis ACCEPTED, implying that job levels are not significant in the opinion of employees on various HRD practices. while Four of the seven Practices that is; training needs assessment, induction and orientation, counseling and coaching, and career guidance and development have the null hypothesis REJECTED implying that the alternate hypothesis is applicable;

H1: There is a significant influence of the job level in the way HRD Practices are implemented in the Ministry of Education in Kenya. This implies the job level is a significant factor in determining how the employees access various HRD practices. 


\section{Discussions, Conclusions and Suggestions}

\subsection{Introduction}

This chapter dwells on the summary of the findings and their discussions. It further puts down suggestions that can improve the HRD practices implementation in the Ministry of Education and Kenya's Public service.

\subsection{Discussions and Conclusions Mean of HRD Practices}

Respondents' opinions show that only Performance Appraisal is done well in terms of Implementation followed by Training Programs Evaluation. Others are far below the mean of 3.00 out of 5.00. it is also clear that most of the HRD practices have huge values of standard deviation pointing to varied opinions which is a clear indication of the discrepancies that are the order of the day in the Ministry.

\section{HRD Practices versus Departments}

Comparing how HRD practices were implemented across departments, brought out a number of contradictory issues worth noting. The first is that despite the fact that HRD is domiciled in the Administration department, it recorded relatively low indices in all aspects except the performance appraisal.

Policy and planning department was high all through with indices about or above the average except in the career guidance and development where it recorded a dismal index of 2.3778 which could mean that the future of the employees in the department sticking with Ministry is bleak. It is also evident that the Field services department has low indices in virtually all the HRD practices. This could be due to the fact that it may not be such a technical department as pertains to education hence always by-passed by various HRD programs. The same could be the problem facing the Administration department.

\section{HRD Practices versus Job Level}

It is very clear that the HRD practices are poorly implemented among the employees as shown by the prevalence indices analyzed. This evidence to the fact that most of the practices are really not well implemented despite the fact that there is funding annually towards that end.

Induction and Orientation though generally poorly implemented is lowest among the lower level cadre. It is highest among the senior level management. This shows that this practice is not taken seriously among the low level.

This trend is quite evident in all the other HRD practices except Performance Appraisal and Training Programs Evaluation where it is lower level staff that shows a higher prevalence than the other Job levels. It is only Performance Appraisal which has an index greater than 3 out of 5 on average.

It is obvious that employees will view Performance Appraisal as punitive since it is taken more seriously than the other HRD practices. It also begs for answers why this practice also ranks highest among the lower level staff, while in the other practices low level staff rank lowest.

Respondents reveal that Induction and Orientation and Career Guidance are the two very lowly ranked Practices. This is contrary to expectations because for employees to perform they need to be tuned to their new environments and also be sure about their future prospects in the organization. This looks like it is grossly over looked in the Ministry of Education in Kenya.

Performance Appraisal and Training Programs Evaluation are the highly ranked of the HRD practices under study. A close look at them reveals a fact that they are more of a reporting practice than developmental practices. In short they are more of evaluative report of what has taken place in training than actual involvement in training. In most cases these are prone to manipulation so as to show the sweeter side of management practices.

Of importance to note is the fact that these two practices have documents to fill hence difficult to forget or assume as compared to the other practices. Career guidance might be a casual advice to staff by the seniors which sometimes might be overlooked as anything serious.

The arguments of bias in terms of Job Level is well supported by the hypothesis testing which reveals that Induction and Orientation, Counseling and Coaching, Training Needs Assessment and Career Guidance and Development Practices show a strong relationship between Job Level and the way HRD practices are implemented. This simply means that some officers may not get development opportunities on account of their Job Level, while others may get development opportunities they do not deserve just because of their Job Levels. It is very necessary that policies are put in place that is not discriminative to any job level and evaluative mechanisms also in place to point out where such weaknesses occur. This has been assumed grossly because it is the senior officers who make decisions and sometimes disregard policies.

It is also prudent that all the HRD practices are documented and a report issued which will be a back up evidence and used to follow up any issues. 


\section{HRD Practices versus Experience}

It is understandable when those in the bracket of $16-25$ years are highest in Induction and Orientation because they are at their prime and therefore occupying new positions due to promotions and transfers. But it beats logic why it should be low among those with experience less than 5 years because these new employees need this practice more than anybody else. Those in the above 25 years also need Orientation because these are employees being prepared for retirement hence need orientation and preparation into their awaiting new ways of life.

This could be caused by a feeling that the new are likely to leave and the old have outlived their usefulness in the Ministry hence no need to waste time and funds on them. This breeds unsettled employees and frustrated retirees.

The Coaching and Counseling practice is high among the employees with more than 16 years. This can be explained by the fact that they are experienced and therefore with a lot to offer to the other employees. It could also mean that as employees tend towards retirement, they need more of Counseling services.

The fact that this practice is poorly practiced among those with less than 5 years experience reveals that in the Ministry of Education it takes time for an employee to establish himself and be noticed. It reveals that the Ministry may not be solving personal and job related problems of newly employed staff.

Training Needs Assessment is once again high among the highly experienced and low among the least experienced. This is probably due to misconception that experience makes employees more knowledgeable. The more experienced are also likely to have charted their career paths hence well informed about their expectations. This means the training needs of the least experienced are never or are poorly captured.

Training Policy formulation looks a bit balanced but still the more experienced enjoy higher implementation. Once this has to do with the feeling that the more experience have more to offer hence more consulted when drawing and formulating training policies. This finally leads to the feeling among the newly engaged that the policies are always crafted to suit the highly placed and the more experienced. What is more discouraging in the whole process is the fact that this practice shows a low implementation index at a mean of 2.67 .

Career Guidance and Development is not much different from the other HRD practices. It shows a mix up among the various experience groups without any specific pattern, but what needs to be noted is it has low implementation at 2.55. All employees need it so as to chart their career paths and lead an enjoyable and satisfied employment life. The assumption that the newly employed don't need it should be discouraged because they need to be aware of what they will and can be in future.

Training Programs Evaluation is evenly implemented in all the experience classes. It is also showing a better index than other practices. These can be attributed the policy requiring a report on any training done. The call for evaluation is necessary for accountability although what appears there may not necessarily be accurate.

Performance Appraisal is the best practiced among all the experience groups. This has been possible because is a mandatory exercise among all the civil servants. It surprises why even the least experienced rank this practice highly even after ranking the others so poorly. It shows that the supervisors are treating performance appraisal as very important because they are evaluated on the same.

The Hypothesis that; there is no significant relationship between the years of experience and the way HRD practices are implemented is rejected for, Induction and Orientation, Counseling and Coaching and Training Needs Assessment implying that there is considerations of experience of an employee before HRD practices are preferred to an employee. This shows a clear bias against employees who have few years of experience. This is contradictory since it is the newly engaged employees who need to be inducted, coached, oriented, counseled and have their training needs captured so as to fit well in employment.

\subsection{Suggestions}

- Timeliness is very important if induction and orientation activities will yield the desired fruits. Induction and orientation should be done immediately new employees are deployed or recruited. Currently the delay is very evident and therefore when done it may not be addressing the problems it was meant for.

- There is need for a centralized training department to avoid the discrepancy between departments, job groups and experience. This is because technical departments of the Ministry seem to be doing their own technical trainings independent of the HRD unit. Technical department should seek for human resource development expertise and guidance before or when handling training programs.

- Reports on TNA and training programs evaluation should be implemented. Research shows that there is no follow up done after reporting. The mentality whereby a report is proof of action needs a re-look so that the impact assessment should be what justifies any activity. 
- Training Needs reports should cover all employees. It is apparent that this is done to the more experienced staff leaving out the inexperienced. As much as there is appreciation of wealth in experience, the needs of the new and the young is very necessary.

- There is necessity to prioritize the HRD practices. This will avoid a situation where only reporting related practices seem to be getting prominence compared to those that involve training of employees. This is a problem today due to the fact training is a one man show either in the central HRD department or in the various technical departments. The need for strengthening the committees is very imperative.

- Coaching and counseling should be done supported by a policy document to guide how it is done. This will ensure that more employees are reached unlike as it is today. Coaching and Counseling is poor among the new employees. It is high among the employees above 16 years of experience. This implies that the newly employed do not have their personal and job related problems addressed. Coaching and Counseling should be an issue for all. Need for fast detection mechanism for those in need and the counselors should have technical skills and knowledge base across the board so that all employees benefit from their services.

- Training Policies Formulation should be seen to be done in all the employee levels. Currently it looks an issue of only the most experienced. To avoid a feeling that the policies are meant for the more experienced it is necessary to engage all employees in the exercise. Policies should also be a reflection of the current issues on the ground and reinforce new ideals and technology.

- Careers Guidance and Development experts need to be deployed in the Ministry. Their absence is very evident. Where they are available they should be accorded more room and time to interact with employees. This is currently not evident.

- It looks like performance appraisal is well ranked because it is a mandatory exercise for all the employees. There is need to compare the implementation index and the result from it so that it is not just a practice. The fear is it is just a normal practice whose results are never revisited.

- Strong policies to guide HRD practices are needed in the Ministry since Hypothesis testing shows there is bias on experience which means policies are either not there or never followed when induction, orientation, coaching, counseling and training needs assessment is done. Policies should be put in place to ensure there is proper selection of employees for various training programs. There are times that policies are in conflict with the realities on the ground. These should be ironed out.

\section{Bibliography}

[1]. Adamson, M (2009). Romancing the New Hire: How Blue Cross Blue Shield Alabama attracts, retains and stays connected with workers through Automated on-boarding. Human Resource IQ. Retrieved from,www.humanresources.com $-23^{\text {rd }}$ March 2012.

[2]. Armstrong, M. and A. Baron (2004), Managing Performance: Performance Management in Action, Chartered Institute of Personnel and Development, London.

[3]. Arshad, H. (2008). Emerging Human Resource Policies and Practices in Select Banks: A Study.(UnpublishedPh.D Thesis). Osmania University, India

[4]. Aswathappa. (2008). Human Resource Management-Texts and Cases (4 ${ }^{\text {th }}$ Ed). New Delhi, India: Tata McGraw Hill Publishing Company.Page 205.

[5]. Augustus, G. Jnr. (1994).Performance Appraisal RateeTraining : A Longitudinal Field Experiment and call for a new Paradigm. Great Britain : University of Pittsburg..

[6]. Bacal, Robert (2010), Performance Management, Performance Appraisal and Employee Reviews, Bacal \& Associates. Sourced from www.work911.com

[7]. Bolar, M. (1970) Evaluating Management Development programs in Industry, Training and Development Journal, 24(3), pg 34-44.

[8]. Bushan, Y.K. (2002), Training Human Resource Development - An Experience in Symbiosis, National HRD Conference

[9]. Charles, Lee (1989), Poor Performance Appraisals do More Harm than Good, Personnel Journal, 68(9).

[10]. Cohen, Ed (2007). Leadership without borders: successful strategies from world-class leaders, Singapore, John Wiley and Sons (Asia) Pte Ltd

[11]. Derek, et all (2005) Human Resource Management, $6{ }^{\text {th }}$ Edition,prentice HallEdinburgh gate, England.

[12]. Dessler, G and Biju Varkkey (2010), Human Resource Management, $11^{\text {th }}$ Edition, Pearson Prentice hall, India.

[13]. Devi, Nalini (1996), A study of Personnel Management Practices in South Central Railway and the Effectiveness of its Operations by the Passengers, a PHD thesis paper, Osmania University.

[14]. Dolezalek (2007) What is your training budget, retrieved from, www.trainingmag.comDPM(2005) Public Service recruitment and training policy, Government Printer, Nairobi, Kenya

[15]. Frances and Roland Bee (2000), Training Needs Analysis and Evaluation, University Press (India), Hyderabad, India.

[16]. Gatewood, D. Robert and Hubert S. Field (2001), Human Resource Selection, $5^{\text {th }}$ edition, Harcourt College Publishers, Orlado, U.S.A.

[17]. Goldstein,I.L., and J,K. Ford (2007) .Training in Organizations , $4^{\text {th }}$ Edition, engage Learning Indian Ltd, New Delhi, India.

[18]. Greer, Charles (2002), Strategic Human Resource Management, Pearson Education (Singapore) PVT Ltd, Indian Branch, New Delhi, India.

[19]. Guthridge, Mathew, Emily Lawson and Asmus Komm (2008), Talent Management, Indian Management Journal, February 2008, pg 58.Hall, B and A. Wasynczuk (2011), Harvard Business Review, "The Gentleman's Three", July/August 2011, pg 157-159.

[20]. Hamblin, A. C (1974).Evaluation and Control of Training, McGraw-Hill, Maidenhead.

[21]. Kenya Power (2012). Our employees: About Kenya power, Kenya Power website, accessed on ${ }^{\text {st }}$ March 2013 via www.kplc.co.ke

[22]. Khera, Shiv (2002), You can win - A step by step tool for top achievers,Macmillam India Ltd, New Delhi, India. 
[23]. Kiiru, D.Muraga (2011). The impact of training and development on performance of staff in organizations within the audit sect or in Kenya: a case of Deloitte and Touche, Kenya. A theses of Kenyatta University Institutional Repository, HF 5667. K5 accessed through http://ir-library.kuc.ac.ke on $2^{\text {nd }}$ March 2013

[24]. Leazes, Francis (1995), Public personnel Management accesses from www.allbusiness.com

[25]. Lwiki, Nelson (2007). Staff Training and Performance: a case of Co-operative College of Kenya.

[26]. Employee development, Jomo Kenyatta University College of Agiculture and Technology, HF 5549.5.T73L85 accessed through www.researchkenya.org on $2^{\text {nd }}$ March 2013.

[27]. Mamoria,C.B and C.V. Gankar(2007), Personnel Management-Texts and Cases, $27^{\text {th }}$ Edition, Himalaya Publishing House, Mumbai, India.

[28]. Mbiti D.M. (1973) Foundation of school Administration, oxford University Press Nairobi, Kenya.

[29]. Mehul, G.T. (2013). Perceived QWL among textile workers. Sankalpa-Journal of Management and research, vol 3. January-June 2013

[30]. Messah, O. B. and S. Kamenchu (2011).The effects of performance appraisal systems on employees in Kenya Tea Development Agencies: a survey of selected factories in Meru County-Kenya. Research Journal of Finance and Accounting, Vol 2,No 3, 2011, ISSN-2222-2847 retrieved from www.iiste.org on $4^{\text {th }}$ March 2013

[31]. Michael, George (2005), Trends in performance Management for the Mid-Market Enterprises, A working paper, CCH Knowledge Point.

[32]. Mihir, K.B. (1988), Managerial Performance Appraisal in India, Vision Books Private Ltd, New Delhi.

[33]. Moses, T. (2006), Management of Human Resources: A Study of HR Practices in Hi-Tech Industries with special emphasis on Retention Practices, A Ph.D Thesis, Osmania University, India

[34]. MSPS (2006), Handbook on Civil Service Staff Induction, Government Printer, Nairobi, KenyaMSPS (2010), Public service has a pool of highly trained employees. The Public Service Update, vol. 2 Jan.- June 2010, pg 21

[35]. Mugenda, O. M. Mugenda, A.G. (1999) Research methods, Quantitative and qualitative Approaches, ACTS press, Nairobi Kenya.

[36]. Narayan, T. and Lakshmi Chopra (2006) Ready for the next leap? Indian Management Journal, Vol 45, Issue No. 3, March 2006.

[37]. Naveen,K. Sharma (2011). Service quality perspective and satisfaction in private banking: An empirical evidence using SERQUAL model in Rajasthan. Prabandh-Journal of Management Education and Research, vol 27. Page 104-114. June 2011

[38]. Nzomo, N (2011). Effectiveness of Employee Training and Development in Kenya: a study of

[39]. Teachers Service Commission, a Master's Theses, Kenyatta University, HF 5549.5.T7N9 accessed through http://irlibrary.kuc.ac.ke on $2^{\text {nd }}$ March 2013

[40]. Olson, C. A. (1994, December). Who receives formal firm-sponsored training in the U.S.? Madison, WI: National Center for the Workplace, University of Wisconsin.

[41]. Ombonyo,T.M.S (2007). Performance Contracts and Performance of Public Sector in Kenya: a case study of National Housing Corporation, an MSc research paper, Jomo Kenyatta University of Agriculture and Technology, accessed through www.researchkenya.com

[42]. Pervaiz, H (Feb 2012). Engagement Matters: The impact of Training nonemployee Turnover.

[43]. Human Resource IQ, retrieved from www.humanresourcesiq.com .

[44]. 23 $3^{\text {rd }}$ March 2012Ponnam, Sonha (2004). Impact of Training on First Generation Entrepreneurs in Tripura, Indian Journal of Industrial Relations, Vol.39,No.4, April 2004, pg 489-504

[45]. Ralphs,L.T. \& Stephen, E. (1986). HRD in the Fortune 500.Training and Development Journal, pg 40-76

[46]. Ramuvhundu M.N (2012), Evaluating the Impact of Local Government Performance Management Systems on Service Delivery, an MBA research paper, University of South Africa, Midrand, South Africa Rao, D.V. (2009), Employee Engagement, APhd Thesis, Osmania University, India.

[47]. Rao, T.V. (1984), Performance Appraisal : Theory and Practice, Vani Education Books, Ghazibad, India.

[48]. Rastogi, P.N. (2001) Knowledge Management and intellectual Capital as a new Paradigm of Business Leadership, Professor IIM Lucknow, Vol.25 no.3, Udyong Pragath, July-September 2001

[49]. Ravindra, K. and RichaAgarwal (2005). Indian and International Perspective on Employee Training Practices: A Trend Report, South Journal of Management, Vol.12, issue No. 1,January-March 2005, pg 79-99

[50]. Reddy, Ratan (2001), In house Training Institutes in Central Public Enterprises, a Ph.D thesis Reich, R. B.,(1991) The Work of Nations:Preparing ourselves for the $21^{\text {st }}$ Century Capitalism.

[51]. New York: Knopf.

[52]. Rowe, Glenn, Albert Connella Jr, Debra Rankin and Douglas Gorman (2005), Leadership Succession and Organizational Performance, Leadership Quarterly-16, number 2, April 2005, pg 197-219.

[53]. Saari, L.M.,Johnson,T.,McLaughlin,S.,\&Zimmerle D.M.(1988). A survey of management training and education practices in U.S. companies. Personnel Psychology,41,731-743.

[54]. Sims, Roland(1993). Public Personnel Management: http:/www.allbusiness.comSingh, S (2011).Education in Manipur.Economic and Political Weekly, June 4-10 2011, VolXLVI No.23, pg 12-13

[55]. Sreekumar J (2009) Training and Development Budget: http:www.associateed Srinivasan, Vasanti (2005), Performance Management: Building a Research Agenda, Human Capital, October 2005.

[56]. Stewart, T. A. (2001, April 2). Mystified by training? Here are some clues. Fortune, p. 184.

[57]. Vance, R.J. (2006), Employee Engagement and Commitment, SHRM Foundations, USA.

[58]. Wanyama, R. E. (2012). Factors affecting training and development of employees within the sugar industry in Kenya: a case study of Nzoia Sugar Company, Kenyatta University Institutional Repository, Master of Business Administration Theses, Kenya accessed through http://ir-ku.ac.ke on $4^{\text {th }}$ March 2013

[59]. Welch Jack (2006), Winning, Harper Collins Publishers, New Delhi, India. 